\title{
Antitrust Law as Mass Media Regulation: Can Merger Standards Protect the Public Interest?
}

\author{
Howard A. Shelanski†
}

Two distinct views of the "public interest" objectives of American communications policy underlie the debate over deregulation of media ownership in the United States. Advocates of deregulation typically view the public interest through an efficiency-oriented model. In that model the policy goal is to promote competition that will lead media companies to better satisfy consumers ' preferences. Opponents of deregulation typically view the public interest through a "democracy" model. In that model the policy goal is to preserve media access opportunities for diverse voices and to promote informed public discussion of important issues. These distinct formulations of the public interest lead to divergent predictions of the consequences should the Federal Communications Commission (FCC), Congress, and the courts leave media concentration to be controlled by general antitrust law. This Article discusses the competing models of the public interest and examines FCC media ownership regulation in the light of those models. The paper then assesses the likelihood that antitrust enforcement could achieve the FCC's public interest objectives. The analysis concludes that in media markets antitrust is unlikely to further the FCC's democracy objectives and also faces serious obstacles to protecting even the economic, efficiency-oriented public interest objectives that are much closer to antitrust law's core purpose. The challenges of protecting the public interest in media markets through antitrust should spark an open debate about what the objectives for mass media policy would be in a deregulated environment and cause policy officials to consider improving antitrust or developing other ways to achieve those objectives.

Copyright (C) 2006 Howard Shelanski.

$+\quad$ Professor of Law, School of Law, University of California, Berkeley (Boalt Hall). The author wishes to thank Stuart Benjamin, Yochai Benkler, Aaron Edlin, Jerry Kang, Jennifer Mnookin, Neal Weinstock Netanel, Robert Post, Phil Weiser, Christopher Yoo, and workshop participants at Berkeley, Georgetown, UCLA, the University of Michigan, and the University of Texas for helpful comments. 


\section{INTRODUCTION}

In June 2003, the Federal Communications Commission (FCC) completed its biennial review of mass media regulation. ${ }^{1}$ The result of that review was a landmark order in which the FCC modified and partially repealed its regulations governing ownership of mass media outlets. ${ }^{2}$ The purpose of the FCC's June 2003 Order was to alter or discard rules that no longer served the agency's longstanding policy objectives of fostering competition, diversity, and localism in mass media markets. ${ }^{3}$

Since its inception, the FCC has implemented media policy through rules governing who may broadcast, what content is broadcast, and the scale and scope of media businesses. ${ }^{4}$ The FCC's mass media regulations have sought to promote programming that is relevant to important public issues and interesting to viewers and listeners. Under the rubric of "the public interest," the FCC has tried to structure a media market that is both competitive enough to satisfy consumers' desires and diverse enough to provide the range of information and viewpoints necessary for informed public discourse. In sum, mass media policy has used varying methods over time to try to serve the interests of both democratic debate and market efficiency. ${ }^{5}$

The 2003 biennial review questioned whether existing mass media regulations were necessary to achieve those established policy objectives. The FCC had promulgated many of those rules when media markets were far more concentrated than they are now. In 1980, for example, there were 9,278 radio stations and 1,011 television stations; about 19.2 million household cable subscribers rcceiving approximately twenty nationally distributed, non-broadcast program networks; 1,745 daily newspapers; and no mass-market Internet. ${ }^{6}$ By 2003 , there were 13,450 radio stations $^{7}$ and 1,747 television stations; ${ }^{8}$ more than 90 million U.S. household cable and

1. Section 202(h) of the Telecommunications Act of 1996, Pub. L. No. 104-104, 110 Stat. 56 (1996), requires the FCC to review its media regulations every two years and to modify or repeal any rules no longer in the public interest.

2. See 2002 Biennial Regulatory Review: Review of the Commission's Broadcast Ownership Rules and Other Rules Adopted Pursuant to Section 202 of the Telecommunications Act of 1996; Cross-Ownership of Broadcast Stations and Newspapers; Rules and Policies Concerning Multiple Ownership of Radio Broadcast Stations in Local Markets; Definition of Radio Markets for Areas Not Located in an Arbitron Survey Area, 18 F.C.C.R. 13,620 (released July 2, 2003) (report and order and notice of proposed rulemaking) [hereinafter Report, 2002 Biennial Regulatory Review].

3. See id. at $13,627-48$.

4. See infra Part Il.

5. See infra Part 1I.B.

6. See Report, 2002 Biennial Regulatory Review, supra note 2, at 13,656-57.

7. Fed. Commc'ns Comm'n, Broadcast Station Totals as of September 30, 2003 (2003), http://hraunfoss.fcc.gov/edocs_public/attachmatch/DOC-241041A1.pdf.

8. Fed. Commc'ns Comm'n, Eleventh Annual Report, Annual Assessment of the Status of Competition in the Market for the Delivery of Video Programming, FCC 05-13, If 78 (released Feb. 4, 
satellite subscribers ${ }^{9}$ receiving 388 nationally distributed, non-broadcast program networks; ${ }^{10} 1,456$ daily newspapers; ${ }^{11}$ and more than 60 million household Internet subscribers. ${ }^{12}$ The mass media landscape had so transformed that the FCC found that several of its longstanding rules governing media ownership no longer served the policy objectives of competition, localism, and diversity for which they had been impIemented. ${ }^{13}$

Importantly, the FCC did not find that those policy goals themselves were either moot or unattainable. ${ }^{14}$ Nor has Congress or the FCC declared an end to the FCC's obligation to promote the "public interest" in media markets or to the government's interest in preventing media consolidation that would undermine a competitive and open "marketplace of ideas." ${ }^{15}$ In the absence of sector-specific ownership rules, this check on consolidation would fall primarily to antitrust enforcement. It is therefore important to ask how well the general antitrust regime that would replace the FCC's $a$ priori ownership restrictions would achieve Congress's and the FCC's long-held policy objectives for mass media in the United States. Even assuming that the media ownership rules are obsolete or insufficiently effective to withstand administrative review, it does not follow that antitrust would be more successful in promoting competition and diversity or would effectively prevent harmful consolidation of media ownership. If, as this Article concludes, there is reason to question the effectiveness of antitrust regulation of media markets, then the underlying policy debate should not end with the FCC's June 2003 Order or the subsequent legislative, administrative, and judicial revisions. Instead, policy makers should either consider new ways to achieve longstanding media market objectives or submit for public debate their implicit decision to withdraw active governmental pursuit of those goals.

This Article presents a more skeptical view of how well antitrust will govern media markets than many advocates of deregulation have presented. It takes as given the policy goals of competition, diversity, and promotion of democratic discourse that are, as a positive matter, currently embedded in the statutes, regulations, and case law relevant to mass media,

\footnotetext{
2005), http://hraunfoss.fcc.gov/edocs_public/attachmatch/FCC-05-13Al.pdf [hereinafter Eleventh Annual Report].

9. Id. I 9.

10. Id. I 145.

11. See Newspaper Ass'n of Am., Facts about Newspapers: A Statistical Summary of THE NEWSPAPER INDUSTRY (2004), http://www.naa.org/info/facts04/dailynewspapers.html.

12. See, e.g., Fed. Commc'ns Comm'n., Availability of Advanced Telecommunications Capability in the United States (Sept. 4, 2004), at 10, http:/hraunfoss.fcc.gov/edocs public/ attaehmatch/FCC-04-208A1.pdf.

13. See Report, 2002 Biennial Regulatory Review, supra note 2, at 13,622-24.

14. See id.

15. See id. at $13,627-28$.
} 
and examines how those goals would fare under antitrust law. ${ }^{16}$ The analysis concludes that antitrust enforcement in its current form is likely to have significant limitations as the exclusive check on media markets. This conclusion does not imply that the FCC should retain its media ownership rules, several of which the FCC quite correctly moved to set aside or revise in the 2003 Order. The conclusion does imply that policymakers concerned with preserving competition and diversity in media markets should supplement their attention to deregulating media ownership with attention to improving the effectiveness of antitrust enforcement in deregulated media markets.

The first part of the Article provides background for the FCC's media ownership proceedings and its June 2003 Order. Part II discusses two distinct concepts of the FCC's public interest objectives at issue in the media regulation debate: proponents of deregulation primarily equate the public interest with satisfaction of consumer preferences (the efficiency model), while opponents of deregulation primarily equate the public interest with the promotion of high quality, diverse, and informative program content (the democracy model). Part II also examines how FCC precedent reflects each of those concepts of the public interest and discusses how the design of the FCC's media ownership rules advances the concepts' distinct objectives. Part III then examines the prospects for furthering either the efficiency-oriented or democracy definition of the public interest through the application of general antitrust law. This Part argues that antitrust will not only be a poor vehicle for achieving non-economic quality and diversity objectives, but will also achieve its conventional goals of competitive efficiency in mass media markets less effectively than in other industries for economic and legal-notably First Amendment-related-reasons. Although this conclusion does not mean that the FCC's ownership rules are preferable to antitrust, the Article argues that a shift from regulation to antitrust to constrain media consolidation will require an accompanying discussion of what the public interest objectives for the mass media industry should be. This discussion must also address changes to antitrust enforcement or new policies, if any, that might be implemented to achieve those objectives. Part IV concludes.

16. This Article therefore does not enter into the normative debate over what the public interest goals of mass media policy should be. Whether govcrnment should even try to promote certain kinds of speech and "edifying" media content, or simply promote satisfaction of current consumer preferences without regard to social or political consequences, is the subject of serious debate and is a question that will bccome increasingly pressing as media markets and media regulation change. 
Congressional, Judicial, and Administrative Trends Toward

\section{DEREGULATION}

In June 2003, the FCC took a major deregulatory step in its mass media policy. In its biennial review of media regulation, the FCC relaxed several longstanding rules governing market concentration and crossownership in the media sector. ${ }^{17}$ The order did not preemptively approve media mergers, but it left them to be controlled by general antitrust law rather than by less discretionary, industry-specific regulations. The FCC's June 2003 Order sparked a strong counter-reaction. ${ }^{18}$ Congress, which had previously tried to reduce the FCC's scrutiny of telecommunications mergers, ${ }^{19}$ and which had ordered the mass media biennial review in the first place, responded to the FCC's Order by drafting legislation that would require more stringent limits on television station mergers. ${ }^{20}$ In an unusual decision, the U.S. Court of Appeals for the Third Circuit, which eventually vacated and remanded several key aspects of the FCC's June 2003 Order, ${ }^{21}$ initially stayed implementation of the Order even though petitioners had not yet exhausted FCC administrative channels. ${ }^{22}$

\section{A. The Telecommunications Act of 1996 and the Shift Toward Deregulation}

To evaluate the strong reaction against the FCC's June 2003 Order, it is helpful first to understand why the FCC changed its media ownership rules in its biennial proceeding and then to examine exactly what the FCC tried to change in its resulting Order. One popular explanation for the FCC's retreat from media ownership rules is that the FCC had its own deregulatory mission and that media ownership was simply the next thing in its path. Syndicated columnist Molly Ivins, for example, ascribed the deregulatory initiative to FCC Chairman Michael Powell and a coterie of "free market zealots" bent on turning over the U.S. media market to a few

17. See Report, 2002 Biennial Regulatory Review, supra note 2, at 13,622.

18. For a concise reflection on some of the controversy surrounding the FCC's Order, see William Fishman, Comments on the FCC's Recent Mass Media Ownership Decision, 53 AM. U. L. REv. 583 (2004).

19. See Telecommunieations Merger Review Aet of 2000, H.R. 4019, 106th Cong. (2d Sess. 2000).

20. See Preservation of Localism, Program Diversity, and Competition in Television Broadeast Service Act of 2003, S. 1046, 108th Cong. $\S 2$ (b) (2003), H.R. 2052, 108th Cong. $\S 2$ (b) (2003) (stating that the purposes of the Aet are to promote localism, diversity of television programming, competition, and to prevent "excessive concentration of ownership").

21. Prometheus Radio Project v. FCC, 373 F.3d 372, 382 (3d Cir. 2004) (overturning the FCC's revised limits on local television, local radio, and cross-media ownership) [Prometheus II].

22. Prometheus Radio Project v. FCC, No. 03-3388, 2003 WL 22052896, at *1 n.1 (3d Cir. Sept. 3, 2003) [Prometheus I]. 
powerful conglomerates. ${ }^{23}$ Similarly, columnist William Safire attributed the prospect of sweeping deregulation to a powerful broadcast lobby and to policymakers who have confused deregulation with sound economics. ${ }^{24}$

Contrary to these opinions, the deregulation of media ownership did not originate with the newly Republican FCC, nor was it simply the result of recent lobbying or ideological bull-headedness. The relevant history of the rules-including their reconsideration and modification by the FCC, their repeal or replacement by Congress, and their rejection and remand by the courts-goes back several years before the biennial review. Indeed, the 1996 Act and a sequence of cases in the U.S. Court of Appeals for the D.C. Circuit helped to set the stage for the FCC's ownership proceedings as well as for the deregulatory direction those proceedings eventually took.

In the 1996 Act, Congress did several things that affected both the nature and degree of media regulation. First, Congress declared that broadcast licensees would have a strong presumption in favor of license renew$\mathrm{aIs}^{25}$ and the FCC implemented a process of virtually automatic "postcard" renewal except in extraordinary cases. ${ }^{26}$ This provision marked a step by Congress in what had by then become a steady evolution away from content-oriented public interest policies enforced through license renewal hearings and toward elimination of constraints on broadcasters' ability to provide the most profitable programming possible, subject to indecency constraints. ${ }^{27}$ Congress also reduced the FCC's power to control the market structure of broadcasting, particularly of radio broadcasting, by raising the number of stations a single licensee could own in a given geographic market. ${ }^{28}$ It similarly raised the ceiling on the percentage of viewing households that a single owner of television stations could serve nationwide. ${ }^{29}$ In 1999, a Democrat-controlled FCC followed Congress's initiative by eliminating the strict prohibition against consolidation of broadcasters in the same market and allowed local station mergers under certain conditions. ${ }^{30}$

Importantly, it was Congress, through Section 202(h) of the 1996 Act, that ordered the FCC to undertake biennial reviews of its mass media regulations and to "repeal or modify any regulation it determines to be no

23. Molly Ivins, FCC and Right-Wing Radio Helping U.S. Press Freedom Slip Away, SALT LAKE City TRIB., Feb. 3, 2003.

24. William Safire, Op-Ed., On Media Giantism, N.Y. Times, Jan. 20, 2003, at A19.

25. See 47 U.S.C. $\$ 309$ (k) (2005).

26. See generally New America Foundation, The Decline of Broadcasters' Public Interest Obligations (2004) (discussing the ease of renewal for licensees).

27. See Stuart Minor Benjamin et al., Telecommunications Law and Policy (200I) at 204-239 (discussing indecency regulation).

28. Telecommunications Act of 1996 , Pub. L. No. 104-104, § 202(b), 110 Stat. 56, 110 (1996).

29. Id. $\S 202(\mathrm{c})(1)$ (addressing limitations for ownership of national broadcast television stations); $§ 202$ (e) (addressing limitations for ownership of dual networks).

30. See 47 C.F.R. $\S 73.3555$ (b) (2004). 
longer in the public interest." ${ }^{, 11}$ Up to the time the FCC issued its 2003 Biennial Review Order, the only court decisions to have interpreted this mandate - both of which came from the U.S. Court of Appeals for the D.C. Circuit - found that it established a deregulatory presumption in the FCC's review of media ownership regulations. ${ }^{32}$ When the U.S. Court of Appeals for the Third Circuit later reviewed the FCC's June 2003 Order, it came to a different conclusion, ruling that Section 202(h) does not establish any presumption in favor of deregulation, although the court did "acknowledge that 202(h) was enacted in the context of deregulatory amendments (the 1996 Act) to the Communications Act." ${ }^{33}$ Regardless of which court's interpretation ultimately prevails, Congress' language in Section 202(h) is certainly not designed to discourage deregulation of media ownership and, as the split between the circuit courts suggests, can plausibly be read to point the FCC in the direction of deregulation.

The courts' role in setting a backdrop for the FCC's 2003 biennial review went beyond interpreting Section 202(h). The U.S. Court of Appeals for the D.C. Circuit rejected and remanded media ownership regulations three times in the three years immediately preceding the FCC's June 2003 Order. The first ruling, Time Warner Entertainment Co. $v$. $F C C,{ }^{34}$ involved cable system ownership, an issue not addressed in the biennial review and that is the subject of a separate, pending proceeding. ${ }^{35}$ The court's ruling is nonetheless relevant to all media ownership regulation by the FCC because, in overturning the FCC's rule limiting the reach of cable systems to $30 \%$ of potential subscribers nationwide, the D.C. Circuit found that the FCC had set the level of the ownership limitation arbitrarily and without sufficient justification in the administrative record. ${ }^{36}$ The court unequivocally placed the burden on the FCC to show that the harms to diversity in absence of its rule were "real, not merely conjectural." 37 The Time Warner Entertainment case clarified to the FCC that its media ownership rules would need to be carefully justified on the basis of actual market evidence rather than anecdote or theory.

31. Telecommunications Act of $1996 \S 202(\mathrm{~h})$. Note that Congress has since modified this provision to call for quadrennial as opposed to biennial reviews. See Consolidated Appropriations Act, 2004, Pub. L. No. 108-199, § 629, 118 Stat. 3, 99-100 (2004).

32. See Fox Television Stations, Inc. v. FCC, 280 F.3d 1027, 1033 (D.C. Cir. 2002); Sinclair Broad. Group, lnc. v. FCC, 284 F.3d 148, 159 (D.C. Cir. 2002).

33. Prometheus Radio Project v. FCC, 373 F.3d 372, 394 (3d Cir. 2004).

34. 240 F.3d 1126 (D.C. Cir. 2001).

35. See generally Fed. Commc'ns Comm'n, Second Further Notice of Proposed Rulemaking, The Commission's Cable Horizontal and Vertical Ownership Limits, FCC 05-96 (released May 17, 2005), http://hraunfoss.fcc.gov/edocs_public/attachmatch/FCC-05-96Al.pdf [hereinaftcr Proceeding on Cable Ownership Limits].

36. See Time Warner Entm't, 240 F.3d at 1132-33.

37. Id. at 1130 (quoting Tumer Broad. Sys., Inc. v. FCC, 512 U.S. 622, 664 (1994) [Turner I]). 
Two years later, the D.C. Circuit issued a second decision that raised the bar for the FCC's justification of media ownership limits. In Fox Television $v . F C C,{ }^{38}$ the court found that the FCC failed to provide any basis for retaining either the national television station ownership limit or the cable/broadcasting cross-ownership prohibition. With respect to the national broadcast ownership cap, the court found that the FCC did not take into account recent data on the number of stations in operation. ${ }^{39}$ Furthermore, the FCC failed to reconcile its refusal to loosen national ownership limits with its earlier decision to loosen local station ownership limitations-a step of perhaps greater consequence because it could reduce the number of owners serving a given locality rather than simply reduce the number of owners nationwide. ${ }^{40}$ The court appeared to accept the FCC's argument that a rule could be retained on diversity grounds even if it did not serve the interests of competition, but simultaneously held that the diversity rationale has limits and must be convincingly justified by record evidence. ${ }^{41}$

The third relevant decision came down shortly after Fox. A different panel of the D.C. Circuit decided in Sinclair Broadcast Group v. FCC that the FCC had failed to justify its remaining local broadcast station ownership limits; in particular, the court held that the FCC had erred by insufficiently justifying its exclusion of non-broadcast media from the eight "voices" that must be left in a market in order for a local station merger to be permitted. ${ }^{42}$ The eourt clarified that neither the precedent recognizing FCC's "wide discretion" to draw administrative lines nor the difficulty of defining "diversity" freed the FCC from its obligation to explain why and provide evidence that its rules are necessary to promote diversity. ${ }^{43}$

The relevant court decisions and legislation show that, by the time the FCC undertook its 2003 biennial review, the momentum was decidedly against the media ownership rules then in place. Congress had signaled its tolerance for less stringent limits for broadcast ownership by raising the cap from $25 \%$ to $30 \%{ }^{44}$ and had arguably tipped the presumption against other existing limits by putting the burden on the FCC to show the continued necessity of its rules in its biennial reviews. ${ }^{45}$ The courts reinforced Congress' mandate by refusing to allow rules to stand absent an

38. 280 F.3d 1027 (D.C. Cir. 2002).

39. Id. at 1052 .

40. See id. at 1051-52; see also Report and Order, Review of the Comission's Regulations Governing Television Broadcasting; Television Satellite Stations Review of Policy and Rules, 14 F.C.C.R. 12,903 (released Aug. 6, 1999).

41. Fox Television Stations, 280 F.3d at 1042.

42. See Sinclair Broad. Group, Inc. v. FCC, 284 F.3d 148, 152 (D.C. Cir. 2002).

43. Id. at 161-62 (quoting AT\&T Corp. v. FCC, 220 F.3d 607, 627 (D.C. Cir. 2000)).

44. See Telecommunications Act of 1996, Pub. L. No. 104-104, § 202(c)(1), 110 Stat. 56, 110 (1996).

45. See $§ 202(\mathrm{~h})$ 
administrative record containing unambiguous, convincing evidence, not just theory, that a rule is needed. Additionally, the courts in both Fox and Sinclair expressly limited the judicial deference the FCC would receive in cases challenging its media ownership regulations.

The 2003 biennial review thus did not spring whole cloth from a new, deregulatory agenda at the FCC. Instead, statutory mandates, past FCC decisions, and the courts played important roles in defining the scope and substance of the review and in creating a complex set of pressures to deregulate. With several of the media ownership rules in flux and at various stages of administrative review, in September 2002 the FCC determined that "it is appropriate for the Commission to consider these rules collectively, as any change to one rule may affect the need for other rulcs to be retained, modified, or eliminated." ${ }^{\prime 46}$ This determination resulted in the sweeping review of mass media ownership regulation that culminated in the June 2003 Order and has since sparked substantial debate and litigation.

\section{B. The FCC's June 2003 Order}

The FCC considered several rules in its 2003 biennial review: (1) the "[n]ational television multiple ownership rule," which caps the number of television stations a single entity may own nationwide; ${ }^{47}$ (2) the local television multiple ownership rule, which limits the number of stations a singly entity may own in a local viewing market; ${ }^{48}$ (3) the radio/television cross-ownership rule, which limits joint holdings among those me$\mathrm{dia}^{49}$ (4) the dual network rule, which prohibits combinations among the four major TV networks; ${ }^{50}$ (5) the newspaper/broadcast rule, which limits cross-ownership of television stations and daily newspapers; ${ }^{51}$ and (6) the local radio ownership rule, which governs the amount of consolidation permissible in a local listening market. ${ }^{52}$ The FCC's June 2003 Order did not eliminate or make changes to all of these rules. In some cases, however, the FCC essentially repealed regulations while in others it made more incremental changes. ${ }^{53}$

With regard to the national television ownership rule, for example, the FCC increased the limit on audience reach from $35 \%$ to $45 \%$ nationwide. ${ }^{54}$

46. Fed. Commc'ns Comm'n, Notice of Proposed Rule Making, 2002 Biennial Regulatory Review: Review of the Commission's Broadcast Ownership Rules and Other Rules Adopted Pursuant to Section 202 of the Telecommunications Act of 1996, FCC. 02-249 (released Sept. 23, 2002), at If 8 [hereinafter Notice, 2002 Biennial Regulatory Review].

47. See 47 C.F.R. $\$ 73.3555$ (d) (2004).

48. See 47 C.F.R. $\$ 73.3555(\mathrm{~b})$.

49. See 47 C.F.R. $\$ 73.3555$ (c).

50. See 47 C.F.R. $\S 73.658(\mathrm{~g})$.

51. See 47 C.F.R. $\$ 73.3555(d)$.

52. See 47 C.F.R. $\$ 73.3555(\mathrm{a})$.

53. Report, 2002 Biennial Regulatory Review, supra note 2, at $\llbracket 2$.

54. Id. ๆ 500 . 
The FCC also relaxed the local television station multiple-ownership rule, allowing an entity to own two local stations in markets with five or more stations, or to own three local stations in markets with eighteen or more stations, so long as only one of the stations involved is within the top four in ratings. ${ }^{55}$ The FCC retained its ban on mergers among the top four national television networks (NBC, ABC, CBS, and Fox). ${ }^{56}$

The FCC made the biggest changes to its cross-ownership rules. It substantially repealed the prior ban on newspaper/broadcast and broadcast/radio cross-ownership and retained the ban (subject to waiver) only in markets with three or fewer television stations. ${ }^{57}$ In markets with four to eight television stations, the order permitted cross-ownership between a daily paper and one television station, as well as cross-ownership between either a daily paper or a television station and a limited number of radio stations. ${ }^{58}$ The FCC completely repealed the cross-ownership rules in markets with nine or more television stations. ${ }^{59}$ Finally, the FCC retained its caps on local radio station ownership but refined its method for defining radio markets. ${ }^{60}$

In each case where the FCC relaxed its ownership rules, its action had the effect of lifting or weakening ex ante prohibitions rather than supplying ex ante approvals. Thus, the fact that the FCC's rules no longer blocked higher television market concentration did not necessarily mean that mergers up to the new maximum levels would be approved. The antitrust agencies would weigh in on significant transactions. Similarly, the relaxation and repeal of the FCC's cross-owncrship rules did not exempt any acquisitions among different media platforms from antitrust scrutiny. If ultimately implemented as a result of the pending remand proceedings, the rule changes from the FCC's June 2003 Order would therefore have the effect of expanding the scope of general antitrust law into areas where specific administrative rules previously did the work. As media ownership regulation ebbs, the responsibility to review transactions that affect the structure of mass media ownership in the United States increasingly shifts to antitrust authorities applying discretionary standards, rather than remaining with the FCC, which traditionally applies much stricter rules. Responses to the FCC's deregulation by Congress and the Courts have only increased the importance of determining how effectively the substitution of antitrust

\footnotetext{
55. Id. ๆ 186.

56. Id. 621

57. Id. ๆ 456,459

58. Id. 466

59. Id. ๆ 472

60. Id. ๆ 239. For a concise summary of the FCC's June 2003 Order, see News Release, Fed. Commc'ns Comm'n, FCC Sets Limits on Media Concentration (June 2, 2003), http://www.fcc.gov/ ownership/documents.html.
} 
for regulation will work. The Third Circuit's remand of the revised rules ${ }^{61}$ provides additional incentive for the FCC, Congress, and, undoubtedly, the courts to review ownership regulations and, in so doing, evaluate the appropriate role for the FCC and other government agencies in light of the potential effectiveness of current antitrust law as the principal protector of the public interest.

\section{The Ensuing Debate}

The FCC's June 2003 Order reducing regulation of media ownership provoked strong opposition and debate. ${ }^{62}$ The reaction diverged markedly from the generally indifferent public response to the wave of mergers in other areas of telecommunications like telephone and cable service that had occurred in the years preceding the mass media biennial review. Indeed, in 2000 Congress tried to nearly eliminate the FCC's jurisdiction over mergers, ${ }^{63}$ relenting only when the $\mathrm{FCC}$ adupted procedures that reduced the scope and burdens of FCC merger review. ${ }^{64}$

The more ardent reaction to potential media consolidation is not, however, surprising; there are differences between what people perceive to be at stake in media deregulation and what they perceive to be at stake in deregulation of ownership transactions in other areas of telecommunications. For example, a merger among telephone companies might lead to slightly higher prices or poorer customer service. Such harms are important but are largely limited to pecuniary considerations and periodic inconveniences. Consolidation among major media providers, in contrast, implicates more than economic concerns. Ownership changes that threaten or that people perceive to threaten the availability of diverse news and information sources, outlets for innovative programming, or coverage of one's favorite football team strike at the heart of civic governance and political debate; at a minimum they might affect the quality of one's leisure time.

Therefore, although substituting antitrust for regulation in the domain of media mergers is in some respects a continuation of institutional trends already underway in U.S. telecommunications, it is notably different from previous changes in the nature and breadth of its perceived impact. The FCC recognized this when it took the issue of media ownership outside the

61. See Prometheus Radio Project v. FCC, 373 F.3d 372, 372 (3d Cir. 2004).

62. For a good source of articles, studies, and FCC filings on both sides of the media ownership debate, see Project for Excellence in Journalism, Does OWnership Matter in Local Television News?: A Five-Year Study of OWNership and Quality (2003), http://www.journalism.org/resources/research/reports/ownership.

63. In March 2000, the House Commerce Committee drafted legislation entitled the Telecommunications Merger Review Act of 2000, which would have substantially curtailed FCC merger review. See H.R. 4019, 106th Cong. (2d Sess. 2000).

64. See Fed. Commc'ns Comm'n, Issues Memorandum for March 1, 2000 Transactions Team Public Forum on Streamlining FCC Review of Applications Relating to Mergers, http:/www.fcc.gov/ transaction/issuesmemo.html. 
conventional confines of the FCC's meeting room in Washington and held public hearings around the country ${ }^{65}$ Commentary on ownership rules has moved from the obscure pages of trade publications and the Federal Register to the editorial pages of America's daily papers and national magazines. Indeed, the prospect of changing how the government regulates media ownership has spurred public debate like no other issue in communications policy. Underlying this debate are two very different visions of what is at stake and of what the purposes of mass media policy should be.

II

\section{Media Regulation and the "Public Interest"}

One's view of the proper purpose of media ownership regulation is likely to determine whether one considers the FCC's deregulatory changes to be evolutionary or revolutionary, or thinks those steps are in the right or wrong direction. The changes in the FCC's June 2003 Order can by some measures be seen as merely modest steps in the long-developing evolution of the method, form, and institutional locus of telecommunications regulation, where the FCC has gradually retreated from a priori rules in the face of market changes. Advocates of deregulation often portray ownership rules as unproductive relics out of step with the realities of modern media markets. ${ }^{66}$ They view the rules as remnants of competition policy implemented to deal with markets in which broadcasters were far more powerful than they are in today's increasingly digital environment of competing cable, satellite, Internet, and broadcast platforms ${ }^{67}$ From this perspective, the policy objective behind ownership rules should be to ensure that media markets respond efficiently to consumer demand ${ }^{68}$ The FCC's June 2003 Order is, in that view, an overdue step toward replacement of rigid

65. See, e.g., Jonathan S. Adelstein, Comm'r, Fed. Commc'ns Comm'n, Remarks at the Northern California Hearing on FCC Media Ownership Rules: Citizen Kane for the 21st Century?: The Defining Moment for Media Ownership (Apr. 26, 2003), http://hraunfoss.fcc.gov/edocs public/ attachmatch/DOC-234045Al.pdf (statements from the San Francisco, California, hearing); News Release, Fed. Commc'ns Comm'n, FCC Commissioner Copps Announces Public Hearing on Media Concentration in Durham, NC, on March 31 (Mar. 26, 2003), http:/hraunfoss.fcc.gov/ edocs_public/attachmatch/DOC-232533A1.pdf (announcing Durham, North Carolina, hearing); Public Notice, Fed. Commc'ns Comm'n, Location Announced for Februrary 27 Field Hearing on Broadcast Ownership: Hearing to be Held at Richmond Convention Center (Feb. 7, 2003), http://hraunfoss.fcc.gov/edocs_public/attachmatch/DA-03-234Al.pdf (announcing Richmond, Virginia, hearing).

66. See, e.g., Daniel E. Troy, Advice to the New President on the FCC and Communications Policy, 24 Harv. J.L. \& Pub. Pol'y 503, 521-23 (2001); Christopher S. Yoo, The Rise and Demise of the Technology-Specific Approach to the First Amendment, 91 GEo. L.J. 245, 276-77 (2003).

67. See, e.g., John F. Sturm, Time for Change on Media Cross-Ownership Regulation, 57 FED. Cомм. L.J. 201, 203 (2005) (discussing how market has changed since ownership regulation began).

68. See Revision of Programming and Commercialization Policies, Ascertainment Requirements, and Program Log Requirements for Commercial Television Stations, 98 F.C.C. 2d 1076 (released Aug. 21,1984 ) (report and order). 
structural regulations that restrict public benefits with more adaptable and case-specific antitrust standards. ${ }^{69}$ For proponents of this perspective, the FCC's changes mark a shift not in policy objectives, but in the proper method for enforcing competition and therefore furthering the public interest in the mass media industry.

In contrast, opponents of deregulation portray the FCC's retreat from its ownership rules not as an evolutionary change in the approach to preserving pro-competitive policy, but as the complete abandonment of a distinct policy objective: the public's interest in a diverse, high-quality, and politically informative media market. Serving consumer demand with greater efficiency is not important from this standpoint; rather, these opponents of deregulation argue that the goal of regulating media markets should be to provide market access for producers of diverse, edifying, and oppositional content. ${ }^{70}$ For those who share this view, FCC rules are the last barriers to a timid, homogeneous, and corporate mass media industry against which there will be no meaningful check after deregulation. The democratic process, not mere economic efficiency, is at stake. ${ }^{71}$ The debate over the proper goals of governing the media industry reveals the basis of the disagreement over whether, upon deregulation, an antitrust regime would protect the policy objectives that the regulations were designed to achieve.

\section{A. Two Conflicting Approaches: The Democracy and Efficiency Models of the Public Interest}

Given that each side of the debate over regulating media ownership invokes the "public interest" as supporting its position, it is not surprising that the opposing sides have developed two distinct definitions of that concept. Proponents of deregulation define the public interest, often implicitly, in terms of fostering a market that does the best possible job of satisfying consumers' programming preferences. This version of the public interest aims for an efficient market, where efficiency means that media companies take consumer preferences as given and produce as much content as people want, in the varieties they want, as cost effectively as possible. Even if "better" programming or content choices might exist for some purposes, the model presumes decisions about what to consume and supply are for

69. Some advocates of deregulation have indeed adopted "[l]et antitrust do it!" as their motto. See, e.g., Progress and Freedom Foundation, Competition Policy in Telecommuncations: Regulation and Antitrust, in THE SKEPTICAL REGULATOR (Sept. 2003), http://www.pff.org/irle/skepticalregulator/ skepticalregulator 1.2.pdf.

70. See, e.g., Steven H. Shiffrin, Dissent, Injustice, and the Meanings of America xi (1999).

71. See Mark N. Cooper, Media OWnership and Democracy in the Digital Information AgE 4 (2003); C. Edwin Baker, Media Concentration: Giving up on Democracy, 54 Fla. L. REv. 839, $840-42$ (2002). 
individuals and media companies, not policy officials, to make. I will refer to this as the "efficiency model" of the public interest.

Opponents of deregulation, on the other hand, typically define the public interest in terms of fostering constitutional and social values of quality and diversity, as well as preserving an effective forum for informed public debate. In this model, what the economic market would dictate gives way at some point to what is necessary to achieve an open and broadly representative marketplace of ideas. Broadcasting a diverse but unpopular program in this model might count as a beneficial promotion of the public interest, not as an undesirable inefficiency. What is important is opportunity for diverse offerings to enter the marketplace, not that consumers prefer each of those offerings to alternatives. I will refer to this as the "democracy model" of the public interest.

The democracy model of the public interest focuses less on consumer demand than the efficiency model does and, at least implicitly, emphasizes the way that consumers' preferences may be formed, not just taken as given, by the supply side of the market. The efficiency model emphasizes satisfaction of aggregated individual desires while the democracy model emphasizes improvement in the quality and diversity of information available to influence civic participation.

At the core of the efficiency model is the idea that regulation should ensure that the public gets what it wants. The "public interest" in this model equates to "what interests the public."72 The efficiency model is quitc plainly at the root of the deregulation under consideration. Both the criticisms of the FCC's ownership rules and the comparative virtues of the antitrust regime are often explained in terms of relative efficiency, with emphasis on the ability of competitive markets to ensure that media companies provide consumers with the kinds of news and entertainment they want. ${ }^{73}$ Proponents of deregulation argue that a fundamental reason to review and revise the FCC's media ownership rules is that the market is increasingly capable of cffectively supplanting regulation in the digital age of multiple media platforms. ${ }^{74}$ Some parties to recent litigation seeking

72. See Cass R. Sunstein, Television and the Public Interest, 88 CALIF. L. REv. 499, 501 (2000) (disagreeing with the efficiency model's premise).

73. See, e.g., Thomas G. Krattenmaker \& Lucas A. Powe, Jr., Regulating Broadcast Programming 45 (1994); Mark S. Fowler \& Daniel L. Brenner, A Marketplace Approach to Broadcast Regulation, 60 TEX. L. REv. 207, 230-33 (1982); Fed. Commc'ns Comm'n, Comments of Fox Entertainment Group, Inc. and Fox Television Stations, Inc, National Broadcasting Company, Inc. and Telemundo Communications Group, Inc., and Viacom, MB Docket No. 02-277 (filed Jan. 2, 2003), Report, 2002 Biennial Regulatory Review, supra note 2.

74. Michael K. Powell, Op-Ed., Should Limits on Broadcast Ownership Change?, USA TODAY, Jan. 21, 2003, available at http://www.usatoday.com/news/opinion/editorials/2003-01-21powell_x.htm. 
deregulation have even argued that the state of market competition is the sole operational criterion for the FCC's biennial review. ${ }^{75}$

In contrast, the democracy model underlies most arguments in favor of retaining the ownership rules. At the heart of that model is the idea that citizens should have ready access to a "public realm" in which they can exchange a wide variety of ideas and viewpoints and in which, as Professor Robert Post puts it, "members of the general public meet to accommodate competing values and expectations, and hence, in which all goals or objectives are open to discussion and modification." 76 The political philosopher Hannah Arendt argued that such a public realm "relies on the simultaneous presence of innumerable perspectives and aspects in which the common world presents;" 77 in other words, it relies on diversity.

The democracy model can be either paternalistic or non-paternalistic. The paternalistic version of the model often casts government in the role of not merely responding to consumer preferences, but also of determining what those preferences should be. As Professor Cass Sunstein puts it, "[t]here is a large difference between the public interest and what interests the public."78 Professor Ellen Goodman similarly argues, "Policy should strive to cultivate, not just satisfy, public tastes in ways that build social solidarity and improve democratic debate." These arguments draw on the expressive values of the First Amendment rather than on the efficiency values of market competition. They hold it to be of little importance that the national cap and cross-ownership regulations might prevent some efficient transactions or might, in the name of preserving access to mass media, put programs or information into the market that marginal consumers prefer less than they would prefer alternatives.

Not all proponents of the democratic values of diversity adopt a paternalistic posture, however. Robert Post has argued that such a "cultivating" role for the state is deeply problematic. He points out that when the state acts as a teacher to inform citizens' preferences, such a role "presuppose[s] an Archimedean point that stands outside of the processes of selfdetermination" as a point of comparison against which the public interest can be judged ${ }^{80}$ But even if such a standard can be found, Post disagrees more fundamentally with permitting the state to act as an educator of preferences, arguing that "citizens engaged in collective self-determination

75. See, e.g., Fox Television Stations, Inc. v. FCC, 280 F.3d 1027, 1027 (D.C. Cir. 2002).

76. Robert C. Post, Between Governance and Management: The History and Theory of the Public Forum, 34 UCLA L. Rev. 1713, 1717 (I987).

77. Hannah Arendt, The Human Condition 48 (1959).

78. Sunstein, supra note 72, at 501.

79. Ellen P. Goodman, Media Policy Out of the Box: Content Abundance, Attention Scarcity, and the Failures of Digital Markets, 19 BERKELEY TECH. L.J. 1389, 1391-92 (2004).

80. See Robert Post, Equality and Autonomy in First Amendment Jurisprudence, 95 MicH. L. REv. 1517, I538 (1997) (book review). 
through participation in public discourse are not students to be taught, but autonomous masters of their fate. They are adults, not pupils." ${ }^{11}$ Although nothing in the democracy model or the First Amendment requires an assumed equality of worth among ideas, official privileging of market access for some ideas over others would be at odds with what Post has called "a constitutional equality of status among persons who propound ideas." Post's conceptualization implies a forum in which citizens choose for themselves which ideas to credit and act on. An accessible and open marketplace of ideas is vital to that process; a market in which the government manages access is not.

What is common to both paternalistic and non-paternalistic views of the democracy model is the desire to preserve citizens' opportunities to express and exchange varied ideas. The purpose of media ownership rules in this model is to preserve structurally open media markets that are more likely to provide the public with diverse, high-quality news and programming, not to conserve a market structure that meets a particular benchmark of economic competition. Because open access to media markets for diverse and oppositional content has long been argued to be essential to a well-functioning marketplace of ideas, ${ }^{83}$ the democracy view predicts that repeal of the rules will foster market concentration likely to produce biased and uncritical news coverage ${ }^{84}$ eliminate localism and innovation in media programming, ${ }^{85}$ and endanger our democraey. ${ }^{86}$

At the heart of the democracy model of the public interest is an important point in any debate over the objectives of public policy. Policy goals are not imposed on society by some exogenous force. Instead, society chooses its collective goals through an evolving process of political, social, and market interactions. We know what society wants because of the viewpoints people exchange and debate, the representatives they elect through the democratic process, and the economic choices they make as consumers. Diversity of viewpoint and open public discourse are therefore not alternative objectives to, say, market efficiency, but are necessary conditions for society to choose market efficiency as a policy goal. Preservation of

81. Id.

82. Robert C. Post, Subsidized Speech, 106 YALE L.J. 151, 189 (1996).

83. See, e.g., Neil Netanel, Copyright and 'Market Power' in the Marketplace of Ideas, in Antitrust, Patents, and Copyright: EU And US Perspectives 149 (Francois Leveque \& Howard Shelanski eds., 2005).

84. See Fed. Commc'ns Comm'n, Comments of Consumer Federation of America, Consumers Union, Center for Digital Democracy, and Media Access Project, MB Docket No. 02-277 (filed Jan. 2, 2003), Report, 2002 Biennial Regulatory Review, supra note 2.

85. See Fed. Commc'ns Comm'n, Comments of the American Federation of Television and Radio Artists and Writers Guild of America, East, MB Docket No. 02-277 (filed Jan. 2, 2003), Report, 2002 Biennial Regulatory Review, supra note 2.

86. See Frank A. Blethen, Opening Address at the lndependent Family Newspaper in America Symposium at the University of lllinois: Only in Variety is There Freedom (Sept. 8, 2002), http://www.iwantmedia.com/people/people19.html (summing up such concerns). 
diversity might therefore come at the cost of short-run, efficient satisfaction of consumers' desires, but only by preserving diversity can society determine that efficiency is the goal it wants. This latter point is why Post says that democracy requires a public forum in which all policy goals are open for discussion and none (except, perhaps, preservation of the forum itself) is taken as given. ${ }^{87} \mathrm{~A}$ lesson of the democracy model is therefore that no society wishing to remain open and democratic can pursue any media policy goal, whether economic efficiency or something else, exclusively and to the preclusion of diversity.

\section{B. The FCC's Historical Application of the Conflicting Models of the Public Interest}

The FCC has pursued both the democracy and efficiency models to varying degrees since receiving its public interest mandate from the Communications Act of 1934. A broad-brush history of the public interest standard reveals an emphasis on the democracy model from the mid-1940s through the 1970s and a shift in emphasis to the efficiency model in the early 1980s. The FCC's emphasis on either model was never exclusive, however, perhaps due to early ambiguity about the statutory and constitutional limits of the FCC's public interest mandate. In 1940 the Supreme Court limited that mandate, declaring in FCC v. Sanders Brothers Radio Station that "the field of broadcasting is one of free competition ... [t]he Commission is given no supervisory control of the programs, of business management or of policy." 88 Yet while the Supreme Court seemed to be steering the FCC towards the efficiency model in 1940, the Court swerved sharply only three years later when it declared in $N B C v$. United States that the Communications Act does not restrict the FCC "merely to supervision of the [broadcast] traffic. It puts upon the Commission the burden of determining the composition of that traffic." 89 The $N B C$ case launched an era of content-oriented approaches to the public interest much more in keeping with the democracy model than the efficiency model. Thus, the FCC issued periodic rules and guidelines in 1946, 1960, 1965, and 1976 specifying the kinds of programming that would be considered in the public interest for licensing purposes. All the while the FCC continued to use its licensing authority to promote localism, diversity of ownership, and diversity of programming. ${ }^{90}$

87. See supra note 73 and accompanying text.

88. FCC v. Sanders Bros. Radio Station, 309 U.S. 470, 474-75 (1940).

89. NBC v. United States, 319 U.S. 190, 215-16 (1943).

90. In 1946 the FCC issued the "Blue Book," establishing three essential programming categories. See Fed. Commc'ns Comm'n, Public Service Responsibility of BroadCast Licensees (1946). In 1960, the FCC expanded the number of public interest categories to fourteen in its En Banc Programming Inquiry. See 44 F.C.C. 2303, 2316 (1972). In 1965 the FCC attempted to make application of the 1960 criteria more objective and consistent for purposes of licensing decisions. 
In the 1970 s and 1980 s, the FCC shifted course. In 1981 the Supreme Court upheld the FCC's decision not to review a licensee's change in programming format from classical music to rock, finding that the FCC had reasonably explained why "reliance on the market is the best method of promoting diversity in entertainment formats." eliminated programming guidelines altogether for radio stations. ${ }^{92}$ In 1984 , it followed by eliminating content guidelines for television broadcasters on the grounds that market incentives were sufficient to ensure that stations produced the programming that viewers desired. ${ }^{93}$ The FCC reinforced these changes with other decisions that increased the likelihood of renewal for incumbent licensees and made it more difficult for non-licensees to challenge license grants. ${ }^{94}$

Although the FCC's shift to an efficiency model of the public interest has endured, that shift has never been absolute. Non-market considerations and important aspects of the democracy model continue to factor into the FCC's approach to protecting the public interest. The FCC continues periodically to introduce initiatives designed to encourage particular kinds of content. Political broadcasting and children's programming havc received specific attention from both Congress and the FCC, although not always through mandatory regulations or statutory requirements. ${ }^{95}$ Additionally, the FCC continues to make program "diversity," in itself, one of the central justifications for regulation. ${ }^{96}$ The FCC also exercises some control over content through its regulation of indecency, an authority it has recently exercised on several well-publicized occasions. ${ }^{97}$ Moreover, the FCC's 2003

Policy Statement on Comparative Broadcast Hearings, 1 FCC 2d. 393 (1965). Finally, in 1976, the FCC required that any license application proposing less than $5 \%$ "local" and less than $5 \%$ "informational" programming be referred to the full Commission for consideration. See Amendment to Section 0.281 of the Commission's Rules: Delegations of Authority to the Chief, Broadcast Bureau, 59 F.C.C. 2d 491 (released May 14, 1976) (order).

91. FCC v. WNCN Listeners Guild, 450 U.S. 582, 595 (1981).

92. See Deregulation of Radio, 84 F.C.C. 2d 968 (released Feb. 24, 1981 ) (report and ordcr).

93. See Revision of Programming and Commercialization Policies, Ascertainment Requirements, and Program Log Requirements for Commercial Television Stations, 98 F.C.C. 2d 1076 (releascd Aug. 21,1984 ) (report and order).

94. See, e.g., Howard A. Shelanski \& Peter W. Huber, Administrative Creation of Property Rights to Radio Spectrum, 41 J.L. \& ECON. 581, 585-89 (1998) (describing FCC removal of multiple barriers to license renewal and challenges to renewal).

95. See, e.g., Policies and Rules Conceming Children's Television Programming, 11 F.C.C.R. 10,660 (released Aug. 8, 1996) (report and order); Policies and Rules for the Direct Broadcast Satellite Service, 17 F.C.C.R. 11,331, 11,405 (released June 13, 2002) (report and ordcr); Children's Television Obligations of Digital Television Broadcasters (released Dec. 16, 2005) (ordcr extending effective date), http://hraunfoss.fcc.gov/edocs_public/attachmatch/FCC-05-211 A 1 .pdf.

96. See, e.g., Broadcast Localism, 19 F.C.C.R. 12,425 (released July 1, 2004) (notice of inquiry).

97. See Enforcement Bureau, Fed. Commc'ns Comm'n, Obscene, Profane and Indecent Broadcasts: Notices of Apparent Liability, http://www.fcc.gov/eb/broadcast/NAL.html (listing recent notices). This article will not address indecency regulation. Indecency rules fall within the category of public interest regulation but are not directly affected by the media ownership rules. Indecency restraints might be considered a third model of public interest regulation focusing on public morals and 
biennial review articulates the promotion of competition and diversity in media markets as objectives of the rules under review. ${ }^{98}$ These objectives, particularly diversity, were central to the FCC's arguments in Fox and Sinclair, the cases in which the U.S. Court of Appeals remanded the national broadcast ownership cap and the local broadcast ownership rule to the FCC for reconsideration..$^{99}$ Therefore, although the efficiency model of the public interest has dominated FCC policy over the past twenty years, the democracy model is still relevant and finds particular expression in the FCC's concern about diversity of media content and ownership, as well as its recurring efforts to promote specific categories of content.

\section{Which Model Were the Ownership Rules Best Designed To Achieve?}

Perhaps because democracy and efficiency goals have both influenced media regulation, the principal motivation for the longstanding ownership rules is not entirely evident. The FCC's move away from direct forms of content regulation toward increasing emphasis on market competition suggests that the FCC would design media ownership rules to serve the efficiency model of the public interest. In form, local and national broadcastownership caps and media cross-ownership rules are structural regulations that govern market concentration, rather than behavioral rules that require access to media platforms or govern the types of content media owners provide to the public. The rules thus appear to be more consistent with objectives of ensuring competitive market performance than with noneconomic objectives of media quality and diversity. Under closer scrutiny, however, suggestions that the FCC tailored its ownership rules to improve the media market's economic performance fray considerably.

\section{Partial Inconsistency with Economic Objectives}

Discussions of competition policy almost always begin with the definition of a "relevant market" in which to assess the market power (in other words, the ability to control price and output) that might result from consolidation of competing firms. ${ }^{100}$ However, it is hard to discern a coherently defined market in which the FCC's ownership rules promote efficient competition.

A "relevant market" captures all the alternative suppliers that consumers view as producing products that can substitute for each other and

\footnotetext{
well being that might apply regardless of whether one otherwise believes the democracy model or the efficiency model to be more central to media policy. Indecency rules would, however, be inconsistent with the view that market efficiency should be the FCC's sole media policy objective.

98. See Report, 2002 Biennial Regulatory Review, supra note 2, at 13,627.

99. See Fox Television Stations, Inc. v. FCC, 280 F.3d 1027, 1042 (D.C. Cir. 2002); Sinclair Broad. Group, lnc. v. FCC, 284 F.3d 148, 159 (D.C. Cir. 2002).

100. See, e.g., U.S. Dep't of Justice \& Fed. Trade Comm'n, Horizontal Merger Guidelines $\S 1.0$ (1992) [hereinafter DOJ/FTC MERGER GuIDELINES].
} 
that therefore compete to attract customers. ${ }^{101}$ Thus, a relevant market is one in which a hypothetical monopolist could raise prices in a profitable, sustained way. ${ }^{102}$ For example, if consumers shift to take-out pizza as soon as the price of take-out hamburgers rises, then hamburgers alone probably do not constitute a relevant market. To understand the true state of competition, one should broaden the market definition to include pizza and perhaps other kinds of food. The relevant product market might turn out to be "take-out fast food." Similarly, if people in neighborhood A are willing to travel to neighborhood B to get take-out, but no farther, then a geographical market definition confined to A provides an incomplete picture of the level of competition. The market should be defined, then, as "take-out fast food in neighborhoods A and B." Policy actions based on narrower market definitions would fail to recognize the competitive effects of excluded suppliers. Policy decisions based on broader market definitions might miss harms to competition that are masked by the improper inclusion of noncompetitors.

If the FCC's ownership rules are aimed at competition and efficiency in satisfying audience demand, the rules should define the markets they address in a manner likely to achieve those objectives. ${ }^{103}$ Yet, neither the broadcast ownership rules nor the media cross-ownership restrictions incorporate a coherent market definition. This suggests that these rules were not designed simply to address competition.

\section{a. Broadcast Ownership Rules}

On its face, the "national television multiple ownership rule," which establishes a national cap on broadcast station ownership, appears to treat broadcast television in the United States as the relevant market. ${ }^{104}$ By preventing any single firm from reaching more than $35 \%$ of the television households nationwide through entities it owns, ${ }^{105}$ the rule seems designed

101. See Herbert Hovenkamp, Federal antitrust Policy: The Law of Competition and its Practice 83 (3d ed. 2005).

102. See DOJ/FTC MERGER Guidelines, supra note $100, \S 1.11$.

103. If the goals are different, for example, to satisfy advertisers or to maximize product diversity nationwide regardless of effects on audience, then the market definition exercise may differ, but neither of these objectives are part of the efficiency model of mass media public interest.

104. See 47 C.F.R. \$ 73.3555(d) (2004) (limiting a broadcaster's "aggregate national audience").

105. In the normal case, market concentration is not based on the customers a firm potentially reaches, but instead by the share of customers the firm actually serves. See DOJ/FTC MERGER GuIDELiNEs, supra note $100, \S 1.41$. A broadcaster that reaches $35 \%$ of households might indeed have no viewers at all if its programming is undesirable. Yet in broadcasting, there is potentially greater competitive significance to share of households reached because there is a limited, perhaps fixed, number of broadcasting licenses available for any given service area. New firms cannot necessarily enter the market, so it is perhaps reasonable to attach greater importance to the number of consumers potentially served rather than actually served. But this argument is challenged by the availability of cable, Digital Broadcast System (DBS), and other substitutes for broadcast television. 
to preserve competition in the broadcast television market. However, that market definition presents two immediate problems.

First, the geographic definition inherent in the national cap is too broad to have anything to do with competition conventionally defined. Consumers in a given locality do not readily substitute stations in distant areas for stations in their areas, since consumers generally have no access to most distant broadcasters, even through satellite or cable. The exception may be for viewers in areas where separate local markets (as defined by the FCC) are close together and some signals from both can be received. Nevertheless, a station in Philadelphia does not compete for viewers or advertising revenues with a station in San Francisco. So using the national cap rule to prevent a broadcasting company that owns a San Francisco station from buying a Philadelphia station will not do anything to affect competitive benefits in either geographical market. The rule does not prevent consolidation within any individual viewer's market, nor does it preserve competition among stations serving any individual viewer.

The geographic market definition is thus too broad to protect or promote satisfaction of consumer preferences either in the localities the would-be acquiring firm already serves or in the local market served by the target firm. On the one hand, the rule bars all acquisitions that would bring the acquiring company over the $35 \%$ cap, even if the acquisition is in a distant geographic market and would have no effect on competition. On the other hand, the rule does not prevent transactions that would reduce competition for viewers in overlapping markets-say acquisition of a Baltimore station by a Washington, D.C., station-if after the transaction the acquirer would still be below the $35 \%$ cap.

The second problem with the national cap's market definition-also a problem for the local broadcast station ownership rule-is identification of the relevant product. While the geographic market definition is too broad for competitive analysis, the product market is arguably too narrow because the rule is limited to broadcast stations. The market definition implicit in the broadcast ownership rules does not consider cable or satellite channels, for example, or other media that might compete with broadcasters to serve, please, and attract viewers. ${ }^{106}$ This was the central flaw that the D.C. Circuit Court of Appeals found with the local broadcast ownership rule in its Sinclair decision. ${ }^{107}$ The fact that a broadcaster might reach a large number of viewers with its transmissions does not mean that those viewers are limited to receiving those transmissions. If viewers do not like the broadcaster's programs, they have options, beyond even the transmissions of other broadcasters. For example, viewers can resort to the many

106. See, e.g., 47 C.F.R. $§ 73.3555$ (b)(2)(ii) (2006) (counting only telcvision broadcast stations for purposes of the local station ownership cap).

107. See Sinclair Broad. Group, Inc. v. FCC, 284 F.3d 148, 163-64 (D.C. Cir. 2002). 
channels cable and Digital Broadcast Systems (DBS) provide, or the myriad video rental options. To be sure, not all of those subscription channels or video rentals are reasonable substitutes for conventional broadcast stations, but many of them are, either individually or in combination with each other. More than $85 \%$ of households in the United States subscribe to either cable or DBS satellite service, ${ }^{108}$ and, indeed, the share of viewing time commanded by the major broadcast networks has steadily declined as cable and DBS have expanded their offerings. ${ }^{109}$

Thus, if the broadcast ownership rules are meant to address competition, then cable and DBS channels should be included in the relevant product market because they are ready substitutes for broadcasters. ${ }^{110}$ Otherwise, the broadcast ownership rules might prevent the consolidation of two broadcasters where such consolidation would not substantially harm consumers because of the availability of substitutes, but they do not prevent or affect consolidation among the DBS or cable programmers that provide the substitutes that compete with the conventional broadcasts.

Because the market definition implicit in the broadcast ownership rules is simultaneously too broad and too narrow, the rules are unlikely to facilitate competition or satisfy viewers' programming desires. The FCC has shown in several contexts that it can do a better job of defining markets for purposes of economic competition, ${ }^{111}$ suggesting motivations for the broadcast ownership rules beyond purely economic objectives.

\section{b. Cross-Ownership Rules}

The FCC's cross-ownership rules-those governing combinations of, for example, newspapers and broadcasters-similarly raise questions about the underlying goals they implicate. As a threshold matter, the crossownership rules are not at all concerned with firms' comparative shares of sales or revenues; calculation of such market shares is the rationale behind defining a relevant market in antitrust analysis to begin with. The rules bar all cross-ownership regardless of how many other newspapers or broadcasters are in the relevant market. Such a sweeping prohibition makes little sense from a competition policy perspective because such a transaction is unlikely to harm consumers if there remain several other newspapers and several other broadcasters competing to serve the same customers.

108. Eleventh Annual Report, supra note 8, 18.

109. Id. $\mid 14$.

110. 47 C.F.R. $\S 73.3555$ (d) (2006).

111. See, e.g., In re Application of GTE Corp. \& Bell Atl. Corp., FCC 00-221 (released June 16, 2000) (memorandum opinion and order) (approving the merger of Bell Atlantic and GTE); Application of EchoStar Commc'ns Corp., Gen. Motors Corp., Hughes Elecs. Corp. \& EchoStar Commc'ns Corp., FCC 02-284 (released Oct. 18, 2002) (hearing designation order) (setting satellite TV merger for hearing hased on likelihood of anticompetitive effects). 
If the national cap rule, by limiting a broadcaster's reach through stations it owns to $35 \%$ of the nationwide audience, defined the product market too narrowly, the definition implicitly established by the crossownership rules may be too broad or too narrow, depending on the rule at issue. Consider the newspaper/broadcast cross-ownership rule. ${ }^{112}$ It implicitly defines a market populated by two major media platforms: broadcast stations and daily newspapers. Both produce news, and in that sense the relevant product market may be something like "news and information." If that is the case, however, it is not clear why other sources of news available when the rule was implemented in 1975, such as radio, should have been excluded from the market. If the purpose of the rule was truly to ensure a competitive news market in which consumers' preferences were wellserved, then consideration of all major news sources that consumers consider substitutes would be warranted before regulation barred any two of them ex ante from consolidating. Absent some basis for bclieving that only broadcast stations and newspapers were such strong competitive substitutes that a cross-ownership restriction between them was warranted, the market may have been too narrowly defined.

Rigorous evidence on substitution among news media is scarce, but at least one recent study finds preliminary evidence that the market definition should be broadened to include not just television and daily papers, but also cable networks, Internet sites, and radio stations. ${ }^{113}$ If the crossownership rules do define the market too narrowly, then it would make more sense economically to have a single rule limiting a given entity's total holdings across all competing platforms rather than drawing strict lines on a platform-by-platform basis. Other evidence points to a narrower market definition and argues that there is relatively little substitution by consumers among news media ${ }^{114}$ If these latter arguments are correct, then the market definition implicit in the cross-ownership rules is too broad, not too narrow, but will still fail to serve the ends of efficient market performance.

Regardless of market definition, platform-specific cross-ownership prohibitions can limit competition in a curious way, especially where the rule ignores questions of market share. A daily newspaper publisher could never bring her expcrtise into the television business by acquiring a station without first getting rid of her newspaper. So over time a pool of potential entrants is blocked from the markct for each different medium. The crossownership rules thus might have the ultimate effect of keeping different

112. 47 C.F.R. $\$ 73.3555$ (c) (2006).

113. See Joel Waldfogel, Fed. Commc'ns Comm'n Media OWnership Working Group, CONSUmer Substitution AMONG Media (Sept. 2002), available at http://hraunfoss.fcc.gov/ edocs_public/attachmatch/DOC-226838A8.pdf.

114. See Fed. Commc'ns Comm'n, Comments of the American Federation of Television and Radio Artists and Writers Guild of America, East, MB Docket No. 02-277 (filed Jan. 2, 2003), Report, 2002 Biennial Regulatory Review, supra note 2. 
kinds of media providers primarily within their original lines of business and impeding competitive entry across platform lines. Neither competitive principles nor promotion of consumer satisfaction would seem to require such a policy, and both objectives might in fact be harmed by it.

\section{Partial consistency with democracy goals}

If the FCC's rules do not provide a coherent framework for improving market competition, they may serve the ends of preserving diversity in the marketplace of ideas. Consolidation of ownership might affect who has the opportunity to transmit content to the market at issue, especially if there are high barriers to market entry by new firms. Ordinarily, the identity of who provides services is unimportant to competitive analysis, so long as a reasonable number of unrelated providers compete in the relevant market. ${ }^{115}$ Thus, if the same competing firms-for example, the same five drug store chains-operate in every geographical market, then antitrust agencies would likely consider the industry competitive and would be unconcerned that on a nationwide basis there are only five distinct entities in the retail drug business. To be sure, one may have concerns about the "franchising of America" and the cultural homogenization fostered in the absence of regional variation in who is providing goods and services. But those are not the concerns of modern antitrust, nor are they necessarily consistent with antitrust law's central purpose of ensuring that markets provide consumers with the goods and services they demand as efficiently as possible.

Yet such concerns about the identity of media owners are a factor in the FCC's broadcast ownership rules. Those rules may not rationally help to maximize satisfaction of consumers' expressed preferences, but they do prevent the same broadcasters from owning the stations in every local broadcasting market. ${ }^{116}$ In that respect the national cap rule touches on concerns central to the democracy model of the public interest. At the heart of that model is the idea that different approaches to news and information should be available and will promote the quality and diversity of programming and national public discourse. Diversity in the identities of noncompeting media providers may benefit core First Amendment values at the national level, because even if broadcasts are consumed locally, they enter the marketplace of ideas and influence discussion, debate, and political participation taking place at a much broader level.

It is potentially valuable under the democracy model to have different broadcasters operating in different markets even if such ownership diversity does not result in conventional competitive benefits. A Philadelphia

115. See DOJ/FTC MERGER Guidelines, supra note 100, $\S 1.51$ (setting out framework for determining market concentration for merger enforcement).

116. See 47 C.F.R. 73.3555(d) (2006) (limiting reach of any broadcaster to $45 \%$ of national audience). 
viewer's satisfaction with current broadcast offerings might not be affected if regulation bars the Philadelphia station owner from owning a San Francisco station. Indeed, that viewer might be hurt by the rule to the extent the merger would have helped the owner gain rights or scale economies that would enable it to transmit more of the kinds of programs Philadelphia consumers demand. Prohibition of the transaction does, however, ensure that someone other than the Philadelphia station owner gets to have an outlet somewhere--San Francisco in this example--through which it can contribute ideas, viewpoints, and information that may affect debate and opinion more broadly. As such, broadcast ownership rules that fit poorly with the efficiency model of the public interest may fit much better with the objectives of the democracy model of the public interest.

Similarly, the FCC's cross-ownership regulations, questionable from an efficiency perspective, are more consistent with the objective of limiting the size of existing media operators in a blunt effort to ensure that different media platforms afford the opportunity for different sets of speakers to reach the market. The rules thus pursue media diversity independently of efficiency consequences. Structural rules do not guarantee that high-quality or oppositional content will enter the marketplace, but the rules do preserve diversity of ownership and thereby might, with some probability, increase the variety of viewpoints bearing on important public questions. ${ }^{117}$ Instead of being viewed as a remnant of outdated, efficiency-oricnted competition policy, the ownership rules might be better viewed as examples of a less economic conception of the public interest.

Both as a matter of precedent and design, the FCC's media ownership rules thus appear to have been simultaneously-although with shifting emphasis over time-pursuing competitive objectives and democracy objectives. It may well be, as the FCC and the courts have found, that the rules fared no better in promoting diversity than they did in promoting competition. But the fact is that democracy objectives were central policy goals that cannot, as a matter of law, suddenly be ignored in a deregulated environment. The objectives of the democracy model, such as diversity, will not disappear unless Congress legislates those objectivcs away or the FCC finds they will be better served by deregulation. The FCC's June 2003 Order and the ongoing reconsideration of its terms thus raise not only the question of whether antitrust standards can do a better job of promoting efficient markets than the ownership rules did, but also whether antitrust standards can preserve the objectives of the democracy model. The next Part addresses how successfully antitrust law is likely to operate with

117. See, e.g., Benjamin M. Compaine, The Impact of Ownership on Content: Does it Matter?, 13 CARDOzo ARTS \& ENT. L.J. 755 (1995) (surveying the relationship between ownership and content diversity). 
regard to both models of the public interest if it replaces regulation as the primary means of regulating media mergers and acquisitions.

III

\section{Can Antitrust Effectively Protect Media Markets?}

Even if the FCC's rules did not serve any of its public interest objectives for mass media, one should not simply assume that an unregulated market governed by antitrust will more effectively achieve those goals. ${ }^{118}$ A more careful assessment of how antitrust will work in media markets is particularly necessary because of the implicit reliance on antitrust enforcement in the deregulation debate. Proponents of deregulation as well as neutral arbiters of the FCC's regulations-such as reviewing courts-have placed great stock in the growth of media competition and diversity in recent years as justification for eliminating the ownership rules. Yet that growth in competition is not etched in stone. To be sure, media growth and competition have increased, in large part because of technology like the Internet, DBS satellite, and digital cable. But this growth has also occurred against the backdrop of the very regulations now under reconsideration for modification or repeal. It is impossible to know exactly how things would look had the rules not been in place. At the very least, however, one can presume that in their absence there would have been at least some tendency towards consolidation. Indeed, if recent experience with the radio market is any indication - ownership deregulation by Congress a decade ago sparked a major wave of consolidation ${ }^{119}$ - then we can expect some attempts at consolidation in the television market and between broadcasters and other media.

Indeed, some increased consolidation may result from deregulation just because antitrust will not even come into play for media transactions that are too small to be reported to the antitrust agencies. Parties must notify the Federal Trade Commission (FTC) and Department of Justice (DOJ) of a merger only if the transaction exceeds $\$ 200$ million or if one party's assets exceed \$I0 million and the other party's assets exceed \$100 million. ${ }^{120}$ The vast majority of all television station acquisitions, for example, have fallen below this threshold, mostly eliminating antitrust review of

118. Some might argue that one of the two sets of public interest goals should be abandoned and that we should therefore be unconcerned with how well antitrust will advance that set of goals. Whether existing public interest objectives are worthwhile is, however, a separate debate that should be conducted explicitly with regard to the merits of the various goals, not implicitly through the mechanisms by which we implement them.

119. See Mass Media Bureau, Fed. Commc'ns Comm'n, Review of the Radio industry, 2001 , at 2 (Sept. 2001) (citing a 25\% decline in the number of radio station owners between 1996 and 2001).

120. See 18 U.S.C. $\$ 18(a)(2000)$. 
consolidation in that marketplace. ${ }^{121}$ This is not necessarily a matter of concern for present purposes, however, because the FCC retains its authority and obligation to review all license transfers even without any of the media ownership rules in place. ${ }^{122}$ On the other hand, to the extent that license transfer review has little bite, especially absent the backstop of the ownership rules, the FCC's license transfer review process and criteria may have to be reconsidered as media ownership regulation evolves. Before using the very market structure that arose under the owncrship rules to justify eliminating those rules, policy makers should be sure that antitrust enforcement and any antitrust-like review by the FCC will effectively preserve the benefits of that market structure.

\section{A. Antitrust and the Democracy Model of the Public Interest}

Opponents of repealing the media ownership rules have argued that deregulation would leave a vacuum in which media quality and diversity would decline. ${ }^{123}$ The validity of this argument depends on whether antitrust can serve democracy objectives, substituting for the rules where they were effective and improving upon them where they were flawed.

Antitrust is by its nature primarily concerned with competition and economic performance defined in terms of prices and quantities of goods (or services) in a given market. Antitrust asks how effectively markcts provide consumers with the products they want on the terms they want. The democracy model of the public interest, in contrast, sees diversity and quality of programming as values in themselves, whether or not the market demands them or would prefer something else. Antitrust analysis may lead to outcomes that, in addition to being competitively efficient, coincidentally benefit democracy goals. The prohibition of a merger between two radio chains might promote efficiency for purchasers of advertising time while simultaneously preserving diversity of formats and editorial approaches for listeners. However, one can certainly imagine cases where the two sets of goals conflict. In many cases, antitrust would count certain outcomes as inefficient market failures, but democracy-oriented policy would see those outcomes as successfully achieving public interest goals.

As a hypothetical example of the potential divergence between antitrust and democracy criteria, suppose there are eight broadcasters in a viewing market, two of which offer mostly sports coverage, four of which show mostly dramas, and two of which show in-depth news reporting. Now imagine that the sports and drama stations command large audiences

121. See Prometheus Radio Project v. FCC, 373 F.3d 372, 414 (3d Cir. 2004) ("Eighty-five percent of station mergers that have taken place since 2000 would not have been subject to antitrust review because the parties' assets fell below these thresholds.").

122. 47 U.S.C. $\$ 310(d)(2000)$.

123. For a discussion of such opinions and a list of relevant citations, see the FCC's biennial review order, 18 FCC Rcd. 13,620, at 9 1 17-52. 
while the news stations attract comparatively few viewers. Assume that most consumers in the market would be happier if they could have even more sports programming in place of the news broadcasts. Assume also that advertisers would similarly be willing to pay more to market their wares during additional drama and sports shows than during news programs. From an economic perspective, this market is inefficient. From a purely economic perspective, broadcasters should reallocate resources to better serve thc preferences of both viewers and advertisers. Suppose the owner of one of the sports stations could purchase the rights to more sports events but lacks a channel on which to broadcast that programming. If that station owner acquired one of the news stations and converted it to a sports station, the transaction would be efficient and in the interest of the consumers in this example. Yet such a transaction would also reduce the already small amount of news programming available in the market and contribute to a trend toward homogeneity in available programming. A positive change according to the antitrust framework can thus be a negative one according to the democracy view of the public interest.

A real example of the clash between efficiency and democracy values occurred during the presidential debates leading up to the 2000 election. One debate between candidates Al Gore and George W. Bush took place at the same time as a baseball playoff game between the New York Yankees and the Oakland A's. ${ }^{124} \mathrm{CBS}$ and ABC both canceled thcir regularly scheduled programming and showed the debates, but NBC gave its affiliates the option of carrying either the debate or the game. Fox did not show the debate at all, opting to show a drama called "Dark Angel." Thcre is no question that the decisions of Fox and NBC were efficient. Who needed a third or fourth channel showing the same debate? Additionally, with the debate available to any viewer who wantcd to watch it, why deprive those who preferred baseball or drama from getting what they wanted? Nonetheless, then-FCC Chair William Kennard publicly chastised NBC and Fox for failing to live up to their public interest obligations: "This is a fundamental obligation.... All the networks should be covering all of the debates live." 125

The democracy model of the public interest clearly provided the basis for Kennard's statement, which suggests a concern that that Fox and NBC distracted viewers from engaging in political discussion by showing other programming and undermining informed democratic discourse. ${ }^{126}$

124. Fourteen Million Opt for "Dark Angel" Over Debate, Associated Press, Oct. 4, 2000, http://www.cnn.com/2000/ALLPOLITlCS/stories/10/04/debate.tv.ap (last visited Mar. 15, 2003).

125. Id.

126. The difficulty with such a theory is, of course, determining who should decide when preemption is in the public interest. In a demonstration of how one person's political discourse may be another's propaganda, FCC Commissioner Michael J. Copps condemned the Sinclair Broadcast Group in 2004 for preempting regular programming to show "an overtly political program in the days prior to 
Kennard's remarks may, at a deeper level, reflect a preemptive concern over the erosion of broadcasters' adherence to "fundamental" public interest norms and about the effects on civic discourse if broadcasters were to provide even less political coverage in the future. This example nonetheless shows the contrast between the economic goals of the efficiency model and the civic education goals of the democracy model in clear relief. ${ }^{127}$

It is instructive to consider how the antitrust approach would differ from the FCC's public interest approach if applied to the above episode. If antitrust authorities observed four firms offering exactly the same product on the same terms when it was clear that it would have been individually profitable for at least one of those firms to offer consumers a different product, then the authorities would suspect illegal eollusion. Whereas the FCC chastised Fox and NBC for not doing what the other networks were doing, antitrust enforcement agencies would have grounds to launch civil and criminal investigations into why four firms were all doing exactly the same thing. This example illustrates the fundamental distinction between the normative benchmarks of antitrust and the regulatory democracy model: unlike the FCC rules, antitrust has no mechanism by which to evaluate or prioritize variety and quality to suit particular social goals over the diversity and quality levels that consumers demand. This situation is analogous to the relationship between competitors and competition in antitrust. Antitrust law protects the process of competition, not the survival of any particular competitor. In the broadcast market, antitrust would protect the competitive process by preventing undue concentration and prosecuting anticompetitive conduct, but it would not protect the survival of any particular programming or programmers. ${ }^{128}$ The latter objective is, howevcr, one the FCC has pursued directly and indirectly through its regulation of media ownership.

One might argue that the above account is unduly pessimistic because antitrust is capable of pursuing dynamic long-term, as opposed to purely static short-term, objectives. To some degree, one can think of the democracy model as pursuing a flow of media content that is in society's best

the Presidential election." FCC Commisioner Copps Criticizes Sinclair Corporate Decision to Preempt Local Stations for Political Broadcast, 2004 FCC LEXIS 5821 (2004).

127. The example also reveals tensions that sometimes exist between the goal of diversity and other eontent-based objectives within the democracy model itself.

128. Originally, antitrust focused much more on the prospects for competitors and the idea of structurally preserving opportunities for market entry and for the survival of small enterprises. These ideas were embedded in the populist roots of the Sherman Act. As Judge Learned Hand expressed in 1945 , "[t]hroughout the history of these statutes it has been constantly assumed that one of their purposes was to perpetuate and preserve, for its own sake and in spite of possible cost, an organization of industry in small units which can effectively compete with each other." United States v. Aluminum Co. of Am., 148 F.2d 416, 428 (2d Cir. 1945). Less than twenty years later, the Supreme Court declared that antitrust law was concerned "with the protection of competition, not competitors," and swept away such solicitousness for any particular group of market participants. Brown Shoe Co. v. United States, 370 U.S. 294, 320 (1962). 
long-term interests. In the case of deregulation, then, one question is whether antitrust could further this initiative by, for example, blocking an acquisition that would make consumers happier today on the grounds that consumers would be even better off later if the transaction did not occur. In other words, proponents of deregulation might argue in the hypothetical example above that antitrust is equipped to recognize that society would actually be happier in the long run if the news station remained a news station and was not switched to a sports or drama station. In principle, antitrust can take dynamic, long-term considerations into account. Antitrust doctrine has long recognized that undue focus on static measures of market performance may harm consumers. Learned Hand, sitting as a district judge, wrote in 1916, "the consumer's interest in the long run is quite different from an immediate fall in prices." ${ }^{\prime 29}$ It is, however, unlikely that even a dynamic antitrust approach would advance democracy objectives.

The fact that courts and enforcement agencies try to be forwardlooking in applying antitrust principles does not mean they can depart altogether from questions of efficiency or evidence of the expected prices and supply of goods in a relevant market. Thus, the DOJ or FTC might approve an increase in market concentration when there is evidence that consolidation of competing firms will lower costs or speed the introduction of some innovative product. ${ }^{130}$ Or those agencies might credit arguments that the relevant market is in flux and that the apparently anticompetitive results of some economic activity will be short-lived as the relevant product becomes obsolete and new firms enter the market with superior substitutes. ${ }^{131}$ But it is another matter to ask antitrust agencies to preserve a less-desired product over a more-desired product on the grounds that long-run social welfare might be increased, especially when arguments for doing so are premised on the idea that what consumers want is not what they should want. Antitrust law passes no judgment on the social costs and benefits of satisfying the preferences consumers express in the marketplace and has long rejected the relevance of non-economic, even if socially beneficial, considerations in enforcement decisions. ${ }^{132}$ Antitrust promotes competition to the end of increasing output and reducing prices, even for products that are

129. United States v. Corn Prods. Ref. Co., 234 F. 964, 1012 (S.D.N.Y. 1916).

130. See, e.g., In re Genzyme Corp.'s Acquisition of Novazyme Pharms., Inc., No. 021-0026 (Fed. Trade Comm'n 2004).

131. See, e.g., Boeing Co., [1997-2001 FTC Complaints \& Orders Transfer Binder] Trade Reg. Rep. (CCH) P 24,295, at 24,123-24 (July 1, 1997) (approving an apparently anticompetitive merger on grounds of McDonnell Douglas' inability to remain a viable innovator and competitor over the longrun).

132. See, e.g., Nat'l Soc'y of Prof'l Eng'rs v. United States, 435 U.S. 679, 688-89, 692 (1978) (finding that Congress, in passing the Sherman Act, emphasized market competition and that only Congress could make exceptions to the primacy of competition). 
understood to be harmful and to have social costs, such as tobacco. ${ }^{133}$ This is not a flaw in antitrust, just a limit to its regulatory scope. Whether the free operation of the competitive market is inappropriate in somc settings is a decision the Supreme Court has found to lie with Congress, not the courts or antitrust agencies. ${ }^{134}$

It is similarly unavailing to argue that antitrust law should be interpreted to ensure the entry and survival of small or fledgling firms that might bring unforeseen benefits to consumers. Exposure to a less-desired good may well change consumers' preferences in a way that is socially or personally beneficial. Indeed, some commentators argue that the preference-forming effects of media make the democracy model of the public interest particularly compelling. ${ }^{135}$ It is hard to question that the relationship between what consumers want and what firms produce runs in both directions. Producers both form and respond to customer preferences, and vice-versa. While competition enhances the interplay between production and preferences, it can also lead to the demise or repositioning of firms that do not give consumers what they want today. Neither courts nor agencies second-guess the exit of firms from the market when such exit occurs through honest competition and the free exercise of consumer choice. While some firms that leave the market due to competitive pressures might have affected consumer preferences in a socially beneficial manner if they had been able to stay in business, antitrust enforcement does not pick and choose among firms that should and should not fail in the face of competition. Such choices would likely be viewed as too speculative and would require antitrust agencies to substitute their judgments of what will improve consumer welfare for the judgments of consumers. ${ }^{136}$ Paternalism is not always bad policy, but it rightly plays no role in modern antitrust law.

Indeed, even the simple idea of using antitrust to preserve market opportunities for new or small firms - part of the original populist motivation for the Sherman Act-no longer has force where such opportunities are in tension with market efficiency. In the 1960s the Supreme Court placed great emphasis on preventing tendencies toward market concentration and made clear that economic efficiency might sometimes have to give way to the value of protecting "viable, small, locally owned businesses."137 That

133. See, e.g., Brooke Group Ltd. v. Brown \& Williamson Tobacco Corp., 509 U.S. 209 (1993); Am. Tobacco Co. v. United States, 328 U.S. 781 (1946).

134. See Nat'l Soc'y of Prof'l Eng'rs, 435 U.S. at 692 (stating that Congress has the authority to determine whether a pro-competitive policy is appropriate).

135. See Goodman, supra note 79 , at 1389, 1404-05.

136. See Fox Television Stations, Inc. v. FCC, 280 F.3d 1027, 1042 (D.C. Cir. 2002); Sinclair Broad. Group, Inc. v. FCC, 284 F.3d 148, 164 (D.C. Cir. 2002) (barring speculative grounds for restraints on media ownership).

137. Brown Shoe Co. v. United States, 370 U.S. 294, 344 (1962); see also United States v. Von's Grocery Co., 384 U.S. 270 (1966) (barring a merger despite low combined market share because of trend toward elimination of small grocery firms). 
emphasis on preserving the structural openness of markets to small players has since vanished from antitrust enforcement in favor of promoting price efficiency, and carries little weight in the FTC/DOJ Horizontal Merger Guidelines. ${ }^{138}$ The Merger Guidelines do not have the force of law and explicitly state that the agencies may pursue different lines of argument in litigation. ${ }^{139}$ Nonetheless, the broad contours of the Merger Guidelines have been widely adopted by the agencies and the courts. ${ }^{140}$

Clearly, preserving market opportunities for new and small media outlets would be consistent with the most content-neutral elements of the democracy model, and it was arguably one of the central objectives of the FCC's ownership rules. As demonstrated, however, even this modest aspect of the democracy approach is not an independent objective of antitrust and, as such, will be accomplished by antitrust only where opportunities for new firms to enter the media market coincide with efficiency-oriented competition enforcement.

\section{B. Antitrust and the Efficiency Model of the Public Interest}

In its current form, it is evident that antitrust would not directly serve the democracy objectives of media policy. The next question is whether antitrust will do better in achieving the economic objectives of the efficiency model of the public interest. On its face, antitrust law appears designed to pursue exactly those objectives: it fosters markets in which producers efficiently satisfy consumer demands. Moreover, antitrust has a well-developed tool kit for identifying and preventing harmful mergers and acquisitions, which enforcement agencies have ample experience applying. For this reason, several commentators have argued that antitrust is the best approach to preventing harmful media consolidation. ${ }^{141}$ That carefully enforced antitrust law is the best approach does not, however, mean its effectiveness should be taken for granted. Media markets present antitrust law with particular difficulties in distinguishing conduct and transactions that harm consumers from those that benefit them.

\section{Difficulties in Defining Media Markets}

First, market definition poses unusual difficulties in the mass media context. As discussed in Part II.C.I, above, defining a market that is useful for making judgments about the competitive effects of a transaction requires determining which products are competitive substitutes for each

138. See generally DOJ/FTC MERGER GuIDELiNES, supra note 100.

139. Id. § 0.1 .

140. See, e.g., Fed. Trade Comm'n v. H.J. Heinz Co., 246 F.3d 708 (D.C. Cir. 2001).

141. See, e.g., Bruce M. Owen, Regulatory Reform: The Telecommunications Act of 1996 and the FCC Media Ownership Rules, 2003 MiCH. ST. DCL L. REv. 671 (2003); Christopher S. Yoo, Vertical Integration and Media Regulation in the New Economy, 19 Y ALE J. ON REG. 171, 231-32 (2002). 
other. A standard approach to this problem is to examine how demand for potentially competitive products changes in response to changes in the price of one of those products. In the absence of price data, it is often particularly difficult to compare consumers' relative preferences for alternative products or to measure the strength of those preferences, presenting a problem for defining media markets. Compounding this problem, some media are free, such as conventional television, conventional radio, many Internet sources, and some weekly newspapers. Other forms of media are priced, such as cable, DBS satellite service, and the print editions of daily newspapers; however, even when antitrust agencies have access to media price data, the data can be hard to interpret. Monthly package prices for cable or DBS frequently convey little information about the relative value to consumers of individual channels within packages. Without accurate and detailed price data, it is hard to estimate "cross elasticities of demand," or the extent to which consumers substitute among different media as relative prices for those media alternatives change.

\section{a. Alternative Methods for Discerning Substitution}

As part of its biennial review, the FCC commissioned a study by Professor Joel Waldfogel that attempts to develop alternative, non-pricebased, methods for measuring consumer substitution among media. ${ }^{142}$ Waldfogel's approach was to first examine how changes in the availability and use of some media at an agregate level have affected the availability and use of other media. Strong negative correlations between two media would suggest substitution between them. Waldfogel then examined data on individuals' comparative use of different media to determine whether, for example, increased use of the Internet was associated with decreased use of other media, like broadcast television or daily newspapers. Again, statistically significant negative correlations would indicate substitution.

The study found some evidence of substitution among various media, but Waldfogel concluded that the results were not sufficient to draw conclusions about the significance of that substitution. ${ }^{143}$ Nor did the methodology permit Waldfogel to determine whether the study captured true substitution between two media or, instead, reflected intervening effects of a third medium because the study's direct correlations method did not account for simultaneous changes in multiple media. ${ }^{144}$ For example, Waldfogel's results seem to show that a decline in daily newspaper consumption correlated with an increase in weekly newspaper circulation. ${ }^{145}$ On one hand, this finding might suggest substitution between the two kinds

\footnotetext{
142. See WALDFOGEL, supra note 113.

143. Id. at 3 .

144. Id. at $21-22$.

145. Id. at 21 .
} 
of newspapers. On the other hand, some other medium like the Internet might be substituting for daily newspapers while the surge in weekly news circulation might be due to unrelated factors and have occurred even if consumption of daily newspapers increased. Thus, even if antitrust agencies can undertake the kind of analysis Waldfogel presents, the inferences that can be reliably drawn for purposes of market definition are limited. Consumer advocate Mark Cooper argues that the FCC study is flawed also because it does not take into account other evidence that shows very little consumer substitution among media alternatives. ${ }^{146}$

Even if dependable methods for measuring substitution among media can be developed-perhaps by building on Waldfogel's study-market definition would be challenging. Suppose demand evidence shows that consumers do not substitute between, say, radio and television news in a particular market. It is still unclear if the lack of substitution is due to preferences based on differences between the general types of media, or to differences in the quality, format, or timing of the content on the particular radio and TV stations at issue. If lack of substitution is due to the second set of differences between media, such as relative quality, then it could be a mistake not to include both radio and television in the relevant market for the transaction at issue. A change in the nature or quality of programming by either the radio or television station in a specific case could bring the stations into direct competition with one another. Lack of content substitution at a point in time (in particular, at the time of the proposed merger) would then mask potential competition between the merging parties. In this example, allowing a radio station and television station in the same market to merge on the grounds that the transaction will not reduce competition would therefore be an error that would harm consumers. Disentangling preferences for general types of media from preferences for specific content and quality would therefore be a difficult challenge in applying antitrust to cross-medium transactions.

If policymakers are able to find a reliable method for measuring consumer substitution among media, then there may be ways for antitrust authorities to determine whether lack of substitution in a particular case is motivated by preferences for one medium over another or by relative preferences for one firm's content. For example, a geographically broad study measuring substitution between radio and television in many different markets would reveal whether consumers systematically prefer radio over television regardless of factors such as quality or timing. Such a study could help agencies weed out the distorting effects of content in a given market. This is not to say that a merger's effects on content are unimportant, just that the effects of content must be controlled to decide whether

146. See CoOPER, supra note 71 , at ch. V. 
two different types of media in a transaction should be seen as part of the same market.

\section{b. Proxies and the Scope of Relevant Markets}

Another approach to market definition difficulties in media markets is to use a proxy for the consumption behavior of viewers. In the broadcast context, antitrust agencies and the FCC have considered the rates advertisers pay and have focused on effects on advertising markets rather than on audiences. ${ }^{147}$ Advertising is a market in which price data is available and cross-elasticities of demand-again, the conventional economic metric for substitution-can be measured. ${ }^{148}$ Because media companies sell advertising, antitrust should examine how particular conduct or transactions affect advertisers as well as viewers. It is not uncommon for a single merger to have impacts in multiple markets and on multiple kinds of consumers. It is less typical for effects in one market to stand as proxies for effects in another. If advertisers have the same preferences as consumers and pay the most for advertising during the most intensely desired programs, then competitive effects on advertisers and effects on viewers correspond.

Antitrust scholars and policymakers recognize, however, that such correspondence is imperfect and can be very weak. Advertisers generally buy time on the most widely viewed programs, which may not be the most strongly desired ones. ${ }^{149}$ Suppose there is a program that twenty million viewers watch and that each values at one dollar and another program that nineteen million viewers watch and that each values at ten dollars. The first program has a social value (economically defined) of $\$ 20$ million while the second has a social value of $\$ 190$ million. ${ }^{150}$ Advertisers seeking to maximize the number of viewers of their ads might choose the more widely viewed but less socially valued program, squandering $\$ 170$ million in consumer surplus. The preferences of advertisers and the preferences of consumers may therefore align only weakly.

147. See Joel I. Klein, Acting Assistant Att'y Gen., Dep't of Justice, Address at the ANA Hotel: DOJ Analysis of Radio Mergers, (Feb. 19, I997), available at 1997 WL 70922 (explaining that determinations of anticompetitive effects are made by "talk[ing] to advertisers ... [and looking at] tools advertisers use to judge the efficacy of their advertising alternatives") [hereinafter Klein Speech]; cf. Fed. Commc'ns Comm'n, Rules and Policies Concerning Multiple Ownership of Radio Broadcast Stations in Local Markets; Definition of Radio Markets, FCC 0I-329, at 19 (released Nov. 9, 200I) (notice of proposed rulemaking and further notice of proposed rulemaking) (noting that while the DOJ uses the advertising market to enforce antitrust, the FCC "seek[s] comment on the DOJ's analysis, both as it relates to the advertising market and the market for listeners") [hereinafter Radio Broadcast Stations Ownership, Rules \& Policies].

I48. See, e.g., Report, 2002 Biennial Regulatory Rcview, supra note 2, at 13,749 (discussing a source of national and regional advertising price data); id. at I3,75 I (discussing measurements of crosselasticity of demand to assess substitution among various kinds of media).

149. See Bruce M. OWen \& Steven S. Wildman, Video Economics 116 (1992).

150. I am assuming for purposes of this example that advcrtisers believe consumers' willingness to watch advertisements does not differ between the two audiences. 
Moreover, what advertisers view as substitutes may not correspond at all to what consumers view as substitutes. It is possible that, for example, consumers are reasonably indifferent about whether they get their evening news from the Internet, television, or radio. The extent of such substitutability is one of the key open questions in the media ownership debate; antitrust authorities will have to address that question as mergers are proposed should the FCC continue to relax and eliminate media ownership rules. On the other hand, as the DOJ and FCC have found, advertisers are often not at all indifferent as to alternative media or content. ${ }^{151}$ Indeed, using the advertisers' perspective, agencies have traditionally defined media markets very narrowly. Both the DOJ and the FCC, for example, have treated radio alone as a relevant market for advertisers that rarely substitute radio advertising with print, electronic, or video media. ${ }^{152}$ In a recent action, the DOJ defined "alternative newsweeklies" as a relevant market because they are "particularly attractive to advertisers" trying to reach a specific demographic group. ${ }^{153}$

Professor Bruce Owen has argued that defining media markets narrowly, as advertisers do, will effectively protect media diversity and hence benefit democracy objectives. ${ }^{154} \mathrm{He}$ reasons that the marketplace for ideas is comprised of many different kinds of media by which a given idea can be communicated. Defining markets narrowly, according to type of medium, would enable antitrust to keep the market for each kind of medium competitive. This approach would in turn lead to a marketplace of ideas that consists of several competitive submarkets and that contains competition both within and across different kinds of media. The problem with narrowly defined markets, however, is that they may obscure the dangers of consolidation among firms from different but overlapping markets and lead authorities to erroneously review a transaction under the more lenient standards for conglomerate mergers. ${ }^{155}$ The result could well be a market structure in which a few firms own and exercise editorial control over a broad portfolio of different kinds of media outlets. While narrow market definition would prevent concentration within categories of media outlets, it

151. See, e.g., Competitive Impact Statement, United States v. Am. Radio Sys. Corp., No. 96 2459, at 6-7 (D.D.C. 1996), http://www.usdoj.gov/atr/cases/f0900/0970.pdf (discussing advertisers with preferences for radio as a medium); Keith S. Brown \& Roberto J. Cavazos, Fed. Commc'ns Comm'n, Empirical Aspects of advertiser Preferences and Program Content of Network TELEVISION, 2003 FCC LEXIS 6801 (2003).

152. See Klein Speech, supra note 147; Radio Broadcast Stations Ownership, Rules \& Policies, supra note 147, at 19 ("In its enforcement of the antitrust laws, the Department of Justice (DOJ), looking at the advertising market, has taken the position that radio advertising constitutes a separate market, finding that advertisers find value in certain of radio's unique attributes.").

153. United States v. Village Voice Media, LLC, \& NT Media, LLC; Proposed Final Judgment and Competitive lmpact Statement, 68 FR 7132 (2003), at 17.

154. Owen, supra note 141 , at 671 ; see notes $53-55$ and accompanying text.

155. Cf. HovenKamp, supra note 101 , at 559 ("Today, conglomerate mergers are not regarded as the competitive threat that they were perceived to be in the 1970s."). 
would not prevent and indeed might facilitate concentration across all types of media. In the end, then, the advertising market proxy may do little to alleviate market definition problems, and precedent for such media market definition is likely to be of limited use in furthering either efficiencyoriented or democracy objectives.

When one considers the conceptual differences between the market for advertising and the "retail" markct for programs (by which I mean the supply of programming to viewers, not advertisers), it is not surprising that they are susceptible to very distinct definitions. The FCC's public interest rules have treated the audience as consumers and programs as the relevant product. In contrast, advertiser-focused merger analysis ${ }^{156}$ essentially treats advertisers as consumers and the audience as the relevant product. In the first framework, broadcasters use advertisers to bring programs to viewers; in the sccond framework, program content or quality are unimportant in themselves because broadcasters only use them to bring viewers to advertisers. If merger review is to successfully advance efficiency-oriented public interest objectives, it must move from the advertiser-focused analysis used in the past to a consumer-focused mode and must overcome the accompanying difficulties of defining markets for media content. ${ }^{157}$

An attempt to proxy consumer preferences more directly while still avoiding the difficulties of measuring media substitution was the FCC's "diversity index," whose purpose was to help identify scenarios in which cross-media consolidation of ownership would harm the public's interest in receiving diverse media viewpoints. ${ }^{158}$ The FCC derived the diversity index from surveys of consumer's reported usage of different sources of news and information in a sample of markets. ${ }^{159}$ The FCC acknowledged, however, that it could not determine consumers' relative preferences among the media they reported using and that it would therefore have to use various proxies to make assumptions about the relative weights to assign different media in the marketplace. ${ }^{160}$ Critics from all sides attacked the diversity index as being either over-inclusive or under-inclusive of media alternatives. ${ }^{161}$ The U.S. Court of Appeals for the Third Circuit eventually rejected the index as based on unjustified decisions by the FCC about which media to include in the index and what weights to assign them. ${ }^{162}$

156. See supra notes 155-156 and accompanying text.

157. On this point, this paper agrees with Maurice E. Stucke \& Allen P. Grunes, Antitrust and the Marketplace of Ideas, 69 ANTITRUST L.J. 249, 297 (2001), which argues that antitrust should try to more aggressively measure competitive effects of media mergers on viewers rather than on advertisers.

158. Report, 2002 Biennial Regulatory Review, supra note 2, at 99 393-394.

159. Id. 1401 .

160. Id. 1 1 $410-411$.

161. Prometheus Radio Project v. FCC, 373 F.3d 372, 404-05 (3d Cir. 2004).

162. Id. at 408-09. 
In the absence of reliable information about media substitution by consumers, or of feasible alternatives for that information, merger authorities could simply presume that media markets are either very narrow (each medium is its own market) or very broad (all media compete in a single market) and proceed from there. As the FCC's experience with the diversity index suggests, such assumptions are analytically troublesome and, moreover, are unlikely to lead to beneficial enforcement decisions. ${ }^{163}$ Consider first very narrow market definitions of the type the Justice Department has used to analyze media markets from the perspective of advertisers. ${ }^{164}$ If every medium is its own market, then cross-media mergers would largely escape scrutiny because they would not increase concentration in any relevant market. At the same time, mergers within a given medium would be more likely to face challenges because enforcement agencies would not view any other kind of medium as a competitor and would likely find the merger to increase market concentration. The underlying economic reality is that market boundaries are less clear, so presuming very narrow markets would lead antitrust enforcers mistakenly to block some mergers within a medium and mistakenly to approve some mergers across media. The perverse result could be that a merger between two of five radio stations in a market would have a systematically harder time getting cleared than a merger between the one daily newspaper and the largest television station in the broader market.

Even when presumptively narrow markets happen to be correct from a consumer-focused competition analysis, mergers can still cause harm even when they do not consolidate market share in any product market. Consider a scenario in which a radio station and a television station merge in a market in which they do not compete for audiences and in which consumers treat the two media as complements rather than substitutes. Consumers may nonetheless suffer harm if the merging firms pursue cost-reductions by consolidating news reporting and entertainment production operations. Even if by some measure efficient, reduced investment in news gathering and production might harm both democratic goals of providing more perspectives and information on issues of importance, and economic goals of satisfying consumers' desire for larger quantities of interesting news and entertainment. Therefore, dispensing with case-by-case market definition in exchange for ex ante presumptions about market boundaries will not free antitrust agencies from careful examination of potential merger harms.

The alternative choice of defining markets very broadly also raises problems. In such cases, every merger is more likely to be cleared because any two firms will be seen to have many competitors and, hence, mergers will appear to have little concentrating effect on the media market. There is

163. See id. at 404-09 (discussing the diversity index and its flaws).

164. See supra notes 153-154 and accompanying text. 
some evidence that new kinds of media have begun to challenge conventional media for audience time. ${ }^{165}$ But the extent to which different media are true substitutes, marginal substitutes, or complements for each other is not adequately understood to presume that market boundaries have so eroded as to eliminate the need for more nuanced market definition. ${ }^{166}$

\section{Difficulty of Interpreting Media Market Structures}

Even if one can accurately define media markets, interpreting what the definitions imply for competition and consumer welfare is also very difficult. Consider first the difficulty of calculating and interpreting the market shares of individual media firms. The reason one defines markets in antitrust is to figure out how many firms produce competing substitutes and to measure each firm's share of the market, usually as a percentage of sales or revenues. Market share, in turn, is relevant in antitrust because it is an indicator, albeit a very imperfect one, of a firm's "market power"-its ability to raise prices, lower output levels, reduce quality, or otherwise indicate that it is insulated from competitive pressure. Under the Merger Guidelines the antitrust agencies challenge mergers that would combine two competitive firms into a single firm whose market share is likely to confer market power. ${ }^{167}$ Generally, the higher the market share, the higher the presumed market power of the firm. But this presumption, porous in the best of circumstanees, is particularly hard to rely upon in media markets.

First, a calculation of market share is only as strong as the underlying market definition. Where markets are difficult to define or products included within a market compete with each other to differing degrees, it will be necessary to look beyond market share to determine the competitive implications of any particular transaction. This is best illustrated through an example. Suppose that ten firms offering differentiated products have been found, for antitrust purposes, to comprise one market. The largest firm currently has a $20 \%$ share of the market and is considering two different mergers, each with a firm possessing a $10 \%$ market share. Using market share as a proxy for market power would indicate that the alternative mergers would have the same likely impact on market performance because both would increase the largest firm's share to $30 \%$. But the two mergers may not have the same anticompetitive effects if the products offered by the two potential merger partners do not substitute equally well for the larger firm's product; although both of the small firms' products were

165. See, e.g., Bruce M. OWen, The Internet Challenge to Television 327 (1999) (arguing that "[t]he analog communication world is in decline, overtaken in important respects by digital technology").

166. See COOPER, supra note 71 , at ch. V (discussing varying consumer demand across types of media).

167. DOJ/FTC MERGER GUIDELINES, supra note $100, \S 1.5$. 
close enough substitutes to be considered part of the same market as the larger firm's product, one small firm may offer a very close substitute while the other small firm's product may be a less proximate alternative. ${ }^{168}$ A merger with the firm producing the closer substitute would be expected to have a larger anticompetitive effect than the merger with the firm producing the more remote substitute. Consequently, courts and agencies must be particularly cautious about drawing inferences from market share in markets characterized by differentiated products. ${ }^{169}$

Second, in a market in which prices paid by consumers are either nonexistent or are only part of a revenue model that also depends on advertising sales, a firm's incentives to exercise market power over its audience are ambiguous or may not lead to anticompetitive conduct or market performance. A cable network, for example, might wish to raise prices for subscribers to a particular network, but might lose advertising revenue as audience size shrinks due to the rising charges, reducing the incentive and ability to profitably raise subscription prices. Shifting focus from prices to other dimensions of market performance, like product variety, results in equally unclear market power effects. A monopolist will not necessarily restrict variety and may, in fact, find it of economic interest to provide greater program choice to viewers than they received under oligopoly (competition among a small number of firms). Whereas competitors may have incentive under certain conditions to duplicate each other's popular formats, thus reducing format variety, a monopolist facing the same market conditions will try to attract new viewers by diversifying formats. ${ }^{170}$

Third, in dynamic markets where market shares may change rapidly over time, it can be hard to know what to make of shares measured at a given moment. If those shares are in flux or if new firms are regularly entering the market, a firm's momentarily large (or small) share of the market may say little about that firm's market power (or lack thereof). Current market shares may reflect only transient popularity of programming. Thus, to discount a firm's competitive impact based on a small market share might lead to a mistakenly benign assessment of a merger involving that firm. For example, to allow a merger between the two weakest of five radio

168. Hotelling first described how firms may compete for customers by offering slightly differentiated products rather than just offering different prices for an identical product. See Harold Hotelling, Stability in Competition, 39 ECON. J. 41 (1929).

169. See Christopher S. Yoo, Vertical Integration and Media Regulation in the New Economy, 19 YALE J. ON REG. 171, 231-32 (2002). Several authors have considered the anticompetitive effects of product differentiation in the electronic media. See, e.g., Patrick Bolton et. al., Predatory Pricing: Strategic Theory and Legal Policy, 88 Geo. L.J. 2239, 2293-98 (2000); James E. Meeks, Predatory Behavior as an Exclusionary Device in the Emerging Telecommunications Industry, 33 WAKE Forest L. REV. 125, 132 (1998).

170. See, e.g., Howard A. Shelanski, Video Competition and the Public Interest Debate, in Telephony, the Internet, and the Media 97-98 (Jeffrey K. MacKie-Mason \& David Waterman eds., 1998) (discussing relevant economic models). 
stations in a market might look harmless based on current market shares and pass muster based on the applicable merger guidelines. If those two stations become popular under joint ownership, however, the assessment of the merger might look quite different. A merger that would not have been allowed if all of the stations in the market had identical market shares might be allowed just because two stations happen to have low market shares at a certain time, to the potential detriment of consumers. One advocate of deregulating media ownership has thus argued that it would be "a serious error" to attribute market power to media firms based on their current revenues or audience shares at any point in time. ${ }^{171}$

Finally, First Amendment values may be at stake if antitrust authorities base merger enforcement decisions on the popularity of a particular media provider's content. If merger clearance hinges on how much market share a particular media outlet has at a given moment, then the antitrust process might appear to be a form of handicapping where the government allows less popular speakers to merge and gain any attendant benefits of consolidation, but denies the same benefits to other speakers based solely on the fact that they are already popular. Commentators have raised this concern as a reason to avoid using current market shares of media operators as measures of market power. ${ }^{172}$

Legal precedent limits but does not eliminate the government's ability to grant different speakers varying economic rights based on their perceived market power. The Supreme Court held in Red Lion Broadcasting Co. v. FCC that searcity of radio frequencies suitable for broadcasting justified government regulation of access to broadcast communications with lesser constitutional scrutiny than would apply to access rules for other kinds of media. ${ }^{173}$ Although the decision has been subject to substantial criticism, the Supreme Court has never overruled Red Lion. In Turner Broadcasting Sys. v. FCC, the Court declined to extend Red Lion to cable or other media. ${ }^{174}$ The Court nonetheless upheld the 1992 Cable Act's must-carry provisions, which require cable operators to carry a certain number of broadcast stations on their systems. The Court, however, ultimately approved such favoring of broadcast media only on the strength of legislative findings that differential economic treatment was necessary to offset the growing power of cable and achieve the government's substantial interest in protecting the free broadcasting medium. ${ }^{175}$

171. Bruce M. Owen, Statement on Media Ownership Rules, Economists INC., Jan. 2, 2003, at 8 (filed in the biennial review proceeding on behalf of Fox, NBC/Telemundo, and Viacom).

172. Bruce M. Owen, Confusing Success with Access: "Correctly" Measuring Concentration of Ownership and Control in Mass Media and Online Services, SIEPR Discussion Paper No. 03-26 (Discussion Draft 2004), http://siepr.stanford.edu/papers/pdf/03-26.pdf.

173. 395 U.S. 367, 388-89 (1969).

174. Turner Broad. Sys. v. FCC, 512 U.S. 622, 640 (1994) [Turner I].

175. See Turner Broad. Sys. v. FCC, 520 U.S. 180, 196-209 (1997) [Turner II]. 
One solution to the practical and legal obstacles to interpreting market share in media markets is to dispense with share data and treat all media outlets within a relevant market as though they have equal competitive positions. ${ }^{176}$ The virtue of this approach is that it eliminates temporary aspects of a media firm's eompetitive position and focuses instead on the medium's underlying ability to transmit content and ideas to the public. Treating media outlets as equal is therefore analogous to measuring market share based on a manufacturing firm's capacity as opposed to its current revenues or sales volumes, an approach that is accepted in antitrust under certain conditions. ${ }^{177}$

Unfortunately, there are problems with using that approach in media markets. One basis for using capacity measures of market share in manufacturing markets is to capture situations in which supply is elastic and a firm could increase its output. Just because two media outlets could, as a matter of physics and economics, be equally popular does not mean that they are likely to become so in any reasonable period of time. Indeed, both courts and commentators have found empirical evidence showing that a small set of powerful media outlets has proven able to retain substantial market share for relatively long periods of time. ${ }^{178}$ So while treating all media outlets as equally powerful would prevent some mistakes, including overestimating the actual market power of popular media and underestimating the potential power of comparatively unpopular media, it would also create converse errors. These errors would likely include overestimation of the competitive force of small media outlets and underestimation of the power of popular media outlets in the marketplace of ideas.

Finally, if antitrust were to adopt the extreme of defining all media as a single market in which all outlets are equal, then this approach would eliminate the need for antitrust altogether in today's media markets. If one really believes that, for purposes of competitive analysis, all television stations, radio stations, Internet portals, blogs, cable systems, and newspapers are equal or potentially equal players, then the market would always be so actually or potentially competitive that there would never be a case for antitrust blocks against mergers. This solution to market-share fluidity essentially defines away the antitrust problem. If its underlying assumptions are true, however, the all-outlets-equal presumption would be a principled basis for dispensing with ownership regulations and leaving antitrust (or nothing) as the default regime governing media market transactions.

176. See Owen, supra note 171 , at 14.

177. See, e.g., Nat'l Aviation Trades Assoc. v. Civil Aeronautics Board, 420 F.2d 209, 215 (D.C. Cir. 1969) (rccognizing that where there is industrial capacity devoted to other uses that could be redeployed in the relevant market, that capacity might be considered to be part of the rclevant market).

178. See, e.g., Prometheus Radio Project v. FCC, 373 F.3d 372, $416-18$ (3d Cir. 2004); Cooper, supra note 71, at ch. V; Philip J. Weiser, Starr: The Creation of the Media: Political Origins of Modern Communication, 103 Mich. L. Rev. 1671, 1691 (2005) (book review). 
Unfortunately, there is little evidence that an underlying assumption of ubiquitous and equal competitors is accurate, and quite a bit of evidence that it is not. The FCC's 2002 survey of media usage showed that the way most Americans obtain news and information has not fundamentally changed in thirty years: through television, followed by newspapers, followed by radio. ${ }^{179}$ While the Internet has had some impact on the public's reliance on these primary news and information sources, it has not thus far fundamentally shifted the competitive dynamics of the media market. A recent study shows that even with the upsurge in online news consumption during the 2004 presidential election, television and newspapers remained the primary sources for information, with the Internet pulling equal audiences to radio but falling far behind the two historically major information sources. ${ }^{180}$ When one considers that many of the popular online outlets are owned by the same television and newspaper sources that already lead the market, or else repackage output from those sources, the Internet's role as an independent competitor appears to be even less significant. Within the Internet itself, market shares also tend to be quite unequal and stable, with major corporate entities retaining a commanding lead. ${ }^{181}$ The stability of market shares in news and information is important, as these are the kinds of content (as opposed to entertainment, which can be very costly to produce) in which one would expect entry barriers to be lowest and competition most fluid. The fact that market shares of different kinds of media and of firms within those media have not shifted quickly suggests that barriers to acquiring market share are more significant than some assume and that the market cannot be casually presumed to be an open and competitive landscape of equally powerful players.

\section{Alternatives to Market Definition}

Given the difficulty of defining media markets and of drawing inferences from those definitions, one might ask whether antitrust agencies are able to sidestep the exercise of formal market definition and still make coherent enforcement decisions. Several influential commentators have argued that proper economic analysis of a merger's effects does not require formal bright-line boundaries. For example, Professor Jonathan Baker, a former Director of the FTC's Bureau of Economics, observed, "if the likely harm to competition from a merger can be demonstrated directly, there exists a market where harm will occur, but there is little need to specify the market's precise boundaries." ${ }^{82}$ Similarly, Professor Janusz Ordover, a

179. See Nielsen Media Research, Fed. Commc'ns Comm'n Media Ownership Working Group, Consumer Survey on Media Usage (Sept. 2002).

180. See The Pew Research Ctr., The lnternet and Campaign 2004 (Mar. 6, 2005).

181. Weiser, supra note 178.

182. Jonathan B. Baker, Contemporary Empirical Merger Analysis, 5 Geo. Mason L. Rev. 347, 351 (1997). 
former Deputy Assistant Attorney General for Economic Analysis at the DOJ, and Dan Wall, a leading antitrust litigator, wrote, "Arguments for and against a merger that turn upon distinctions between broad and narrow market definitions are, to an economic purist, an inadequate substitute for, and a diversion from, sound direct assessment of a merger's effect." 183 Professor Andrew Gavil has also argued that market share evidence should not trump direct evidence of market power, such as reduced output or higher prices. ${ }^{184}$

An approach that looks at direct evidence of harm could avoid the need to conduct the formal analysis of placing alternative media outlets either totally inside or totally outside a given market. Real-world markets often have no such bright-line boundaries, and markets for differentiated products like media might therefore be more usefully viewed as a continuum, where different products compete with one another to varying degrees and may be hard to break down into clear and distinct markets.

There are, however, both practical and doctrinal difficulties to surmount before sidestepping the threshold exercise of market definition in the analysis of media mergers and acquisitions. To begin with, case law supporting a departure from market definition in merger cases is thin. In antitrust contexts other than merger review, courts have agreed that substituting direct evidence for market definition can be appropriate. For example, the U.S. Court of Appeals for the Second Circuit stated, "If a plaintiff can show that a defendant's conduct exerted an actual adverse effect on competition ... this arguably is more direct evidence of market power than calculations of elusive market share figures."185 Similarly, the Supreme Court held in FTC v. Indiana Federation of Dentists that "proof of actual detrimental effects, such as a reduction of output, can obviate the need for an inquiry into market power, which is but a surrogate for detrimental effects." $" 186$

The thrust of the above statements is that market definition is an indirect way of showing the effects of economic conduct and should not stand in the way of considering direct evidence of harm to competition. Despite the logical applicability of this wisdom to mergers, however, it is not as feasible to use direct evidence of competitive harms in lieu of market definition in merger cases as it is in antitrust cases involving past or ongoing conduct with observable consequences. Merger investigations are prospective in that they almost always occur before the transaction in question is

183. Janusz A. Ordover \& Daniel M. Wall, Understanding Econometric Methods of Market Definition, 3 AnTitrust 20, 20 (1989).

184. See Andrew 1. Gavil, Copperweld 2000: The Vanishing Gap Between Sections 1 and 2 of the Sherman Act, 68 AnTIT RusT L.J. 87, 99 (2000).

185. Todd v. Exxon Corp., 275 F.3d 191, 206 (2d Cir. 2001).

186. Fed. Trade Comm'n v. Ind. Fed'n of Dentists, 476 U.S. 447, 460-61 (1986) (internal quotations omitted). 
consummated and its effects can be empirically verified. Enforcement agencies will therefore usually have only predictions of harm instead of proof of actual effects. ${ }^{187}$

Even if antitrust manages to surmount some of the obstacles to using direct evidence in lieu of market definition theories in merger review cases, doctrinal difficulties remain. Given the relatively circumstantial and predictive case for harm in merger cases compared to other antitrust contexts, courts have proven much less willing to adopt a flexible view of market definition and are morc likely to dismiss or discount a merger challenge if the agency is unable to establish a clear market boundary. The Justice Department lost its recent bid to block the merger between Oracle and PeopleSoft in large part because the trial court found that the Justice Department failed to prove the accuracy of the product and geographic markets it had alleged in its complaint. ${ }^{188}$ Interestingly, the trial judge in Oracle was well aware that it can be "difficult to identify clear breaks in the chain of substitutes sufficient to justify bright-line market boundaries" in markets with similar but differentiated products. ${ }^{189}$ This recognition did not, however, lead the court to diminish the government's burden of proving a market definition that would support its theory of harm in the case.

Even where the prospective nature of a merger's effects is not a problem, perhaps because there is relevant evidence of past conduct in the marketplace or because the merging firms have announced certain plans, it could be difficult to assess whether those cffects are in fact harmful to competition and consumers. For example, suppose a merger yields less news but more sports. At a broad level, there is the same amount of programming, but perhaps antitrust agencies should be focusing more narrowly on the category of "news" in which output reduction will occur instead of looking broadly at "programming." Once the analysis attempts to determine the proper categorization of programming for the competitive analysis, however, the core issue circles right back to the determination of which kinds of programming compete with each other, again raising all of the market definition problems.

One response to the difficulty of assessing the effects of programming changes is simply to decide that reduction in any type of programining will count as a harm and weigh against the merger. Another tough question then arises because the antitrust agencies would have to decide how to wcigh

187. Antitrust agencies can likely do a better job of assessing and predicting the potential harms from a merger by using more sophisticated analysis of a transaction's expected welfare effects. See Michael L. Katz \& Howard A. Shelanski, Merger Analysis and the Treatment of Uncertainty: Should We Expect Better? (Sept. 29, 2005) (working paper), available at http://ssrn.com/abstract=821234. But the basic point remains that assessment of actual harm will be harder to measure for future mergers than for past conduct.

188. See United States v. Oracle Corp., 331 F. Supp. 2d 1098, 1108, 1175 (N.D. Cal. 2004).

189. See id. at 1120 (internal quotations omitted). 
compensating benefits - in this example, the increased sports programming-against the harm of reducing the other type of programming involved. If consumers want more sports programming and less news, then the efficiency model of the public interest would encourage the authorities to approve the transaction. But the calculation of consumer welfare might be more complicated than meets the eye. Similar to the correspondence between competitive effects on advertisers and effects on viewers discussed above, ${ }^{190}$ audience surveys might not reveal the harm if consumers watch more sports but actually value news more. The merged firm might either mistakenly add more sports or, more likely, add the sports because advertisers pay higher rates on such programming than on news. On the other hand, a more serious problem might involve consumers who lose news programming and do not watch sports; if such consumers exist, then sports fans gain while news watchers lose as a result of the merger. Thus, it is necessary to determine at this point whether antitrust authorities should look at consumer welfare in the aggregate and approve the merger or look at the news watchers' uncompensated harm and block the merger.

Tradeoffs between losers and winners in merger analysis are not confined to media mergers. Some consumers may suffer welfare losses in almost any type of transaction. In the conventional case where the government approves a merger, however, losses are limited because there remain close substitutes for the consumers. Moreover, any merger benefits may flow to the same consumers who suffer the losses, so the losers themselves receive compensating benefits. Yet in the media market example, the costs and benefits are more likely to flow to distinct sets of consumers, with no mechanism by which the winners compensate the losers. The existence of substitutes is unclear because substitutes have not been determined nor media markets defined, since we used direct evidence of harm to avoid those difficulties to begin with. This example illustrates the difficulty of weighing harms and benefits in the media merger review equation in the absence of market definition.

\section{First Amendment Considerations in Applying Antitrust to Media Markets}

The First Amendment potentially adds a challenge to antitrust law's ability to preserve either democracy or efficiency-oriented goals in the mass media industry. Antitrust has played a role in media markets in the past, and the DOJ and FTC have not encountered constitutional barriers to blocking mergers between newspapers, radio stations, or the owners of satellite television systems. The Supreme Court long ago made clear that "[a]ll are alike covered by the Sherman Act. The fact that the publisher

190. See discussion infra Part III.B.1. 
handles news while others handle food does not . . . afford the publisher a peculiar constitutional sanctuary" from antitrust enforcement. ${ }^{191}$ But the fact that most media merger cases do not pose a First Amendment problem does not necessarily mean that constitutional concerns will be absent should the basis for an antitrust enforcement action be content based. Challenges to media mergers have generally steered clear of First Amendment problems because, to the extent they have looked at effects on content at all, they have done so only in a general and neutral way. ${ }^{192}$ As already discussed, however, antitrust will be most effective in furthering even the efficiency-oriented policy goals for media markets if it directly considers how ownership changes will affect the markets for content. Applying antitrust enforcement to protect audience welfare will require antitrust agencies to examine more directly what mergers will do to the quantity, quality, and mix of content available to viewers, listeners, and readers.

Several commentators have argued that First Amendment values actually require competition enforcement to be stronger in media markets than in other markets because, similar to democracy-oriented public interest regulation, the role of antitrust should be to promote an open, highly atomized market in which output is diverse and speakers of varying popularity or economic size can broadcast their content to consumers. ${ }^{193}$ Their arguments imply that consolidations among media companies should trigger antitrust challenges at even lower levels of market concentration than would raise concern in other industries.

First Amendment law is, however, more likely to limit rather than expand media merger scrutiny. The Constitution does not require the government to increase collective speech so much as it prohibits the government from restricting individual speech. ${ }^{194}$ Thus, even if limiting the size of one speaker's megaphone would permit more speakers to be heard, the government must show that this restriction is content-neutral, essential to a legitimate objective, and no more burdensome than necessary. ${ }^{195}$ In

191. Associated Press v. United States, 326 U.S. 1, 7 (1945).

192. See, for example, Complaint at 1 1 37-55, United States Dep't of Justice v. Echostar Commc'ns Corp., No. 1:02CV02138 (D.D.C. Oct. 31, 2002), available at http://www.usdoj.gov/atr/cases/f200400/200409.htm, in which the agency talks mostly about price and other economic effects and refers to competition to provide local channels and a variety of programming in a very general way and without reference to types of content.

193. See CoOper, supra note 71 , at 34; LAWrence Lessig, Code and OTHER Laws of CYBERSPACE 184 (1999) (explaining that eliminating spectrum allocation would enable "[a]ll modes of transmission... [to] compete with each other, and speakers would have the benefit of the most competitive mode").

194. See Robert Post, Meikeljohn's Mistake: Individual Autonomy and the Reform of Public Discourse, 64 U. Colo. L. REv. 1109,1110 (1993) (discussing Supreme Court hostility to the agenda of increasing collective speech or increasing the quality of public discourse where doing so limits any individual speech).

195. See Tumer Broad. Sys., Inc. v. FCC, 512 U.S. 622, 662 (1994). 
keeping with this mandate, antitrust authorities acting in media markets must be attentive to the speech rights of the merging parties regardless of the speech or content benefits the enforcement action might provide to non-parties or consumers. Therefore, while as a normative policy matter some might argue that democracy values would be served by more stringent antitrust enforcement, as a positive legal matter such stringent enforcement may be limited by the very constitutional provision upon which the democracy model most often relies. ${ }^{196}$

The Supreme Court has consistently held that economic regulation of media ownership should be subject to intermediate scrutiny under the First Amendment so long as the regulations are content-neutral and do not have the purpose of restraining speech. ${ }^{197}$ While those decisions make it more likely that neutral limits 'on media ownership will survive facial First Amendment challenges, other precedent suggests limits on deference to an agency's specific applications of such ownership limits.

Consider first the D.C. Circuit's decision in Time Warner Entertainment $C o$. v. FCC, which vacated the FCC's limit on cable system consolidation. ${ }^{198}$ The court in Time Warner first reaffirmed that Congress's grant of authority to the FCC to promote diversity and preserve competition in the media marketplace was valid and, because Congress based its decision on reasonable inferences from available evidence, the statute did not facially violate the First Amendment. ${ }^{199}$ Next, however, the court held that regardless of the legal validity of the FCC's statutory authority to regulate cable ownership, to survive the intermediate standard of scrutiny the FCC "must still justify the limits that it has chosen as not burdening substantially more speech than necessary" and "demonstrat[e] that the recited harms [of consolidation beyond a particular level] are real, not merely conjectural." 200 Tellingly, the court rejected the FCC's rule that limited a single cable owner's size to $30 \%$ of subscribers on the grounds that "the Commission has pointed to nothing in the record supporting a nonconjectural risk of anticompetitive behavior, either by collusion or other means." ${ }^{201}$ The courts applied similar logic in overturning FCC rules

196. For a discussion of "positive liberty" theories of the First Amendment, see Yochai Benkler, Free as the Air to Common Use: First Amendment Constraints on Enclosure of the Public Domain, 74 N.Y.U. L. REv. 354, 377-86 (1999). For a critique of such theories, see Christopher S. Yoo, The Rise and Demise of the Technology-Specific Approach to the First Amendment, 91 GEO. L. J. 245 (2003).

197. See Turner Broad. Sys., 512 U.S. at 662; FCC v. Nat'l Citizens Comm. for Broad., 436 U.S. 775, 800-02 (1978).

198. Time Wamer Entm't v. FCC, 240 F.3d 1126, 1144 (D.C. Cir. 2001).

199. Id. at 1131 .

200. Id. at 1130 .

201. Id. at 1136 . 
limiting ownership of broadcast television stations and its rule preventing broadcast/cable cross-ownership. ${ }^{202}$

The Time Warner, Fox, and Sinclair cases suggest that even where an agency has specific authorization from Congress to pursue media diversity and competition through content-neutral rules, courts will require strong evidence that any restriction on ownership is necessary to prevent genuine harms. There is no reason to think the DOJ or FTC will receive any greater deference than that extended to the FCC. ${ }^{203}$ In fact, the antitrust agencies are in an even weaker position for pursuing media diversity and competition than the FCC was prior to the 2003 biennial review. The antitrust agencies enforce only general competition statutes like the Sherman Act and the Clayton Act. Unlike the FCC, they have no specific authorization from Congress to limit media ownership to further statutory public interest policies. Moreover, if antitrust enforcement in media markets is truly going to protect consumer weIfare, it should be able to make judgments not just about how consolidation will affect the number of media firms or the quantity of programming, but also about how the merger will affect the quality and availability of particular kinds of programs in the relevant market. Such application of the Merger Guidelines to limit media ownership appears likely to face at least the same "intermediate" scrutiny under the First Amendment faced by the FCC's content-neutral regulations, in which case courts will require the enforcement agencies to provide strong evidence of real harms to justify blocking a merger. How far the Supreme Court's Associated Press dictum would extend to merger review focusing on speeific media content is therefore an open question.

\section{CONCLUSION}

The foregoing discussion demonstrates that antitrust faces many practical and legal challenges to pursuing the public interest goals of media market regulation. On its face, antitrust law appears ill suited to achieve democracy objectives of media policy, but this Article demonstrates that antitrust will also face substantial barriers to achieving efficiency model objectives, which mirror the very objectives for which antitrust enforcement is designed. For these reasons, policymakers must make several improvements to the antitrust toolbox and develop enforcement approaches specifically geared to the challenges of media markets before they can

202. See Fox Television Stations, Inc. v. FCC, 280 F.3d 1027, 1053 (D.C. Cir. 2002); see also Sinclair Broad. Group, Inc. v. FCC, 284 F.3d 148, 159 (D.C. Cir. 2002) (stating that "neither the Commission nor the intervenors gave any plausible reason for believing the CBCO Rule is necessary to further competition").

203. See Sinclair Broad. Group, 284 F.3d at 164-65; Fox Television Stations, 280 F.3d at 1052-53; Time Warner Entm't, 240 F.3d at 1144. 
comfortably rely on antitrust to preserve media competition as the media market becomes deregulated.

One lesson from the foregoing discussion is that we should approach deregulation of media ownership with a realistic appraisal of what will stand in its place. General antitrust law will have difficulty vindicating both sets of public interest objectives that implicitly underlie the FCC's ownership rules. The debate over ownership should take this fact into account and either acknowledge that deregulation marks a retreat from those objectives or make clear that policymakers must explore new methods of meeting public interest goals. A second lesson is that policy tools for achieving the public interest cannot be identified without first determining policy objectives. Antitrust as mass media regulation fares better or worse depending on one's view of appropriate public interest goals. Additionally, addressing how to improve antitrust law's operation in the media market and whether to use regulatory approaches in addition to antitrust depends on what society wishes to accomplish. This procedural point has important substantive implications. The very notion of a debate over policy goals implies the exchange of differing arguments and preferences, implying that preservation of a diverse public forum must itself be one of the goals of media policy. But whether diversity is a primary goal or is secondary to efficiency, the extent to which it will be pursued and whether it will be accomplished through the market or some kind of intervention are open to question. The answers to those questions should not be determined $s u b$ rosa in the regulatory process.

Assuming that deregulation is not a deliberate retreat from public interest goals, Congress and the relevant agencies should next make efforts to craft new approaches to those goals for media markets in the United States. These efforts should focus on improving how antitrust is applied in such markets. There are good models for similar efforts by the antitrust agencies to develop enforcement approaches geared toward the challenges of particular kinds of markets. A recent example is the FTC's October 2003 study of the proper balance between intellectual property rights and competition policy. ${ }^{204}$ Other examples include the FTC/DOJ 1995 Antitrust Guidelines for the Licensing of Intellectual Property ${ }^{205}$ and the agencies' 1996 Statements of Antitrust Enforcement Policy in Health Care, ${ }^{206}$ the

204. "To Promote Innovation: The Proper Balance of Competition and Patent Law and Policy," A Report by the Federal Trade Commission (Oct. 2003), http://www/ftc/gov/us/2003/10/ innovationrpt.pdf.

205. See U.S. Dep't of Justice \& Fed. Trade Comm'n, Antitrust Guidelines for the LiCENSING of INTEllectual Property (Apr. 6, 1995), http://www.usdoj.gov/atr/public/guidelines/ 0558.pdf.

206. See U.S. Dep't of Justice \& Fed. Trade Comm'n, Statements of antitrust Enforcement Policy in HealthCare (Aug. 1996), http://www.usdoj.gov/atr/public/guidelines/ 1791.pdf. 
latter of which is supported by a standing DOJ Healthcare Taskforce in the Antitrust Division. ${ }^{207}$ Given the tremendous social and economic importance of media markets, a similar task force devoted to antitrust in media markets would provide a promising way to anticipate challenges and improve the ability of antitrust to achieve long-standing public interest objectives.

An initial project for such a task force would be to build on work the FCC and DOJ have already done and conduct a thorough study of competitive incentives, consumer behavior, and metrics for market definition in the mass media industry. A better empirical understanding of how media markets work, combined with careful analysis of the dynamics of differentiated product markets and uncertainty in merger review, will likely make antitrust enforcement in media markets more effective. It may be that the media market will ultimately perform well enough without intervention to satisfy all aspects of the public interest. But if not, antitrust must be ready to step in and recognize harmful consolidation.

Finally, the qucstionable prospects for antitrust as the primary enforcer of public interest objectives in mass media policy should inform review of the FCC's administrative decisions on ownership. It may well be, as the FCC found, that its ownership regnlations have not achieved their objectives. In that case, eliminating such regulations would reduce the costs of rigid, ineffective rules, and replacing those rules with an antitrust regime would cause no immediate negative effects. But, as this Article has illustrated, it is possible that the FCC should continue to play a role in regnlating media ownership, especially in transactions too small to require mandatory pre-merger notification to the DOJ or FTC. Certainly, the end of significant media ownership regulation by the FCC does not, without legislative action, mean the end of mass media policy. The FCC and Congress should therefore supplement their decision-making processes with regard to media ownership rules with a discussion of the future of mass media policy and of how antitrust agencies and the FCC can best achieve its objectives.

207. See antrtrust Division, U.S. Dep't of Justice, Health Care Task force Recent ENFORCEMENT ACTIONS, http://www.usdoj.gov/atr/public/health_care/2044.htm (describing task force and mission). 
